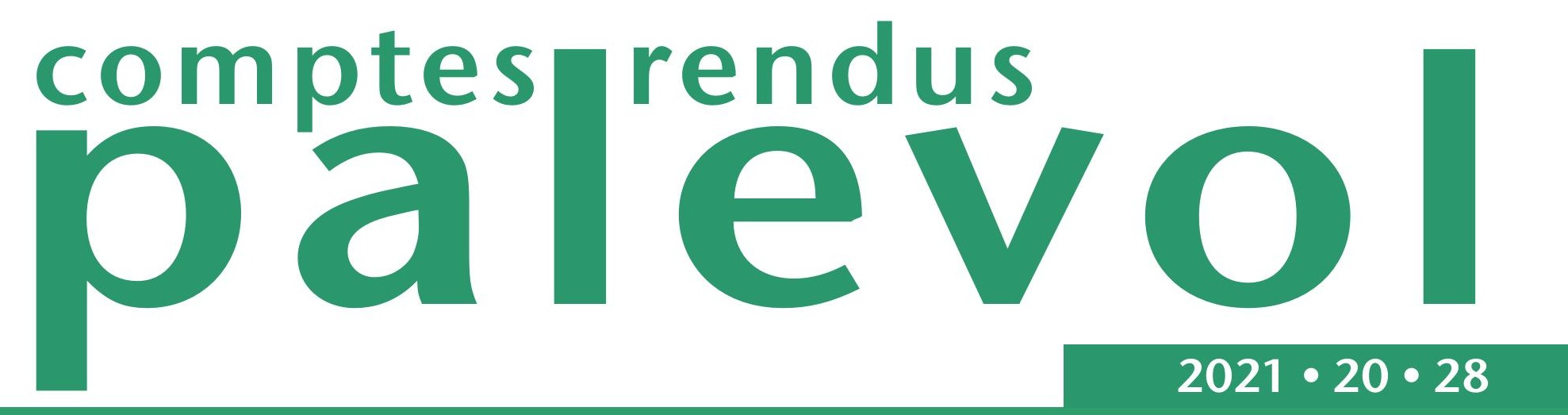

\title{
Prolagus Pomel, 1853 (Lagomorpha, Mammalia) in the framework of the Pliocene faunal rearrangements in central Europe
}

Stanislav ČERMÁK, Chiara ANGELONE \& Blanca MONCUNILL-SOLÉ

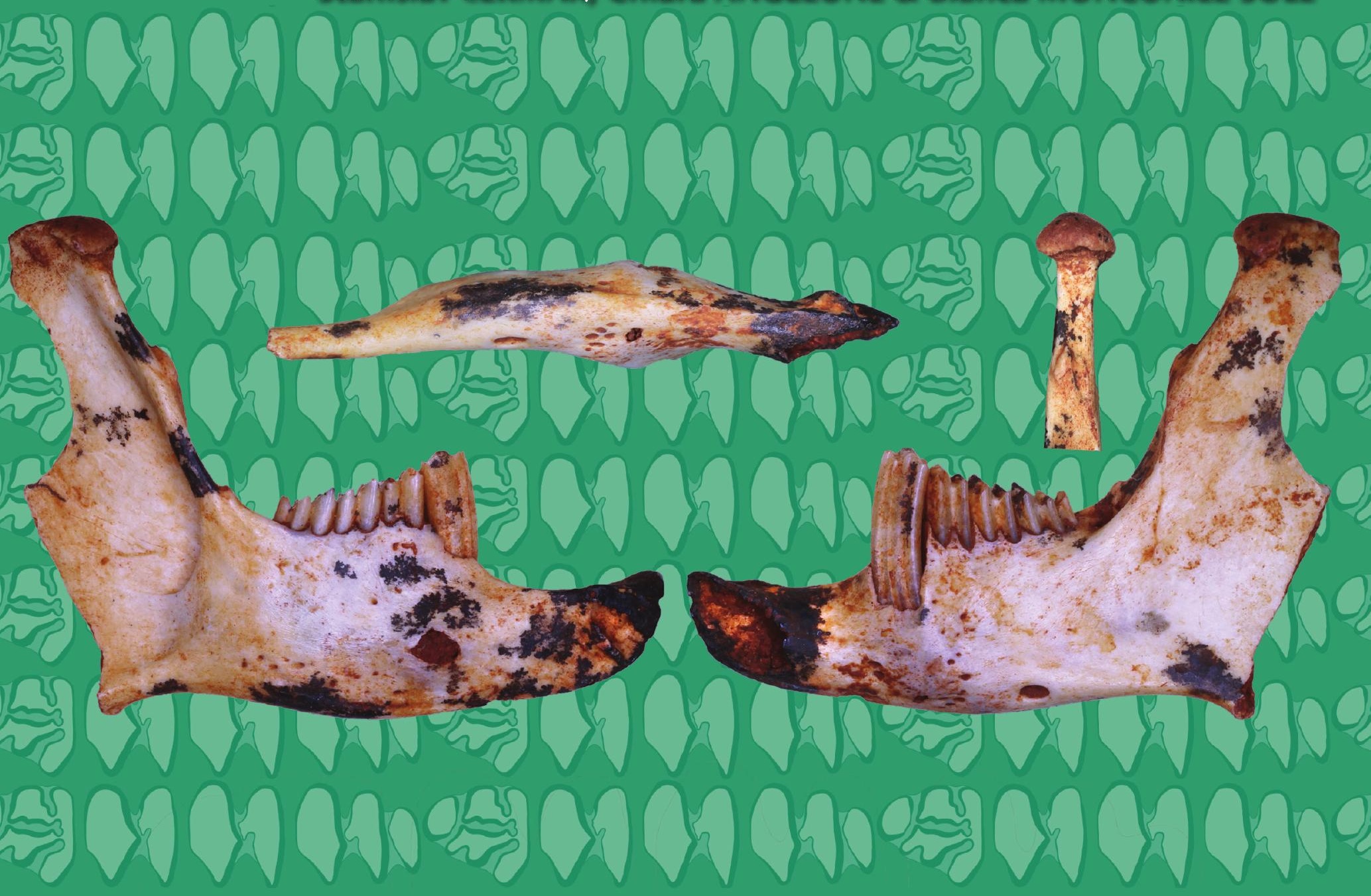

art. 20 (28) - Published on 28 June 2021

www.cr-palevol.fr 
DiRECTEURS DE LA PUBLICATION / PUBLICATION DIRECTORS:

Bruno David, Président du Muséum national d'Histoire naturelle

Étienne Ghys, Secrétaire perpétuel de l'Académie des sciences

RÉDACTEURS EN CHEF / EDITORS-IN-CHIEF: Michel Laurin (CNRS), Philippe Taquet (Académie des sciences)

AssistANTE DE RÉDACTION / AssistANT EDITOR: Adenise Lopes (Académie des sciences; cr-palevol@academie-sciences.fr)

MISE EN PAGE / PAGE LAYOUT: Fariza Sissi (Muséum national d'Histoire naturelle; fariza.sissi@mnhn.fr)

RÉviSIONS LINGUISTIQUeS DES TEXTES ANGLAIS / ENGLISH LANGUAGE REVISIONS: Kevin Padian (University of California at Berkeley)

RÉDACTEURS ASSOCIÉS / ASSOCIATE EDITORS ( ${ }^{*}$, took charge of the editorial process of the article/a pris en charge le suivi éditorial de l'article):

Micropaléontologie/Micropalaeontology

Maria Rose Petrizzo (Università di Milano, Milano)

Paléobotanique/Palaeobotany

Cyrille Prestianni (Royal Belgian Institute of Natural Sciences, Brussels)

Métazoaires/Metazoa

Annalisa Ferretti (Università di Modena e Reggio Emilia, Modena)

Paléoichthyologie/Palaeoichthyology

Philippe Janvier (Muséum national d'Histoire naturelle, Académie des sciences, Paris)

Amniotes du Mésozoïque/Mesozoic amniotes

Hans-Dieter Sues (Smithsonian National Museum of Natural History, Washington)

Tortues/Turtles

Juliana Sterli (CONICET, Museo Paleontológico Egidio Feruglio, Trelew)

Lépidosauromorphes/Lepidosauromorphs

Hussam Zaher (Universidade de São Paulo)

Oiseaux/Birds

Eric Buffetaut (CNRS, École Normale Supérieure, Paris)

Paléomammalogie (mammifères de moyenne et grande taille)/Palaeomammalogy (large and mid-sized mammals)

Lorenzo Rook* (Università degli Studi di Firenze, Firenze)

Paléomammalogie (petits mammifères sauf Euarchontoglires)/Palaeomammalogy (small mammals except for Euarchontoglires)

Robert Asher (Cambridge University, Cambridge)

Paléomammalogie (Euarchontoglires)/Palaeomammalogy (Euarchontoglires)

K. Christopher Beard (University of Kansas, Lawrence)

Paléoanthropologie/Palaeoanthropology

Roberto Macchiarelli (Université de Poitiers, Poitiers)

Archéologie préhistorique/Prehistoric archaeology

Marcel Otte (Université de Liège, Liège)

COUVERTURE / COVER:

Mandible of Prolagus sp. from the early Pliocene of Hungary. Author of photos: Stanislav Čermák.

Comptes Rendus Palevol est indexé dans / Comptes Rendus Palevol is indexed by:

- Cambridge Scientific Abstracts

- Current Contents ${ }^{\circledR}$ Physical

- Chemical, and Earth Sciences ${ }^{\circledR}$

- ISI Alerting Services ${ }^{\circledR}$

- Geoabstracts, Geobase, Georef, Inspec, Pascal

- Science Citation Index ${ }^{\circledR}$, Science Citation Index Expanded ${ }^{\circledR}$

- Scopus ${ }^{\circledR}$

Les articles ainsi que les nouveautés nomenclaturales publiés dans Comptes Rendus Palevol sont référencés par / Articles and nomenclatural novelties published in Comptes Rendus Palevol are registered on:

- ZooBank ${ }^{\circledR}$ (http://zoobank.org)

Comptes Rendus Palevol est une revue en flux continu publiée par les Publications scientifiques du Muséum, Paris et l'Académie des sciences, Paris Comptes Rendus Palevol is a fast track journal published by the Museum Science Press, Paris and the Académie des sciences, Paris

Les Publications scientifiques du Muséum publient aussi / The Museum Science Press also publish:

Adansonia, Geodiversitas, Zoosystema, Anthropozoologica, European Journal of Taxonomy, Naturae, Cryptogamie sous-sections Algologie, Bryologie, Mycologie.

L'Académie des sciences publie aussi / The Académie des sciences also publishes:

Comptes Rendus Mathématique, Comptes Rendus Physique, Comptes Rendus Mécanique, Comptes Rendus Chimie, Comptes Rendus Géoscience, Comptes Rendus Biologies.

Diffusion - Publications scientifiques Muséum national d'Histoire naturelle

CP $41-57$ rue Cuvier F-75231 Paris cedex 05 (France)

Tél.: 33 (0)1 40794805 / Fax: 33 (0)1 40793840

diff.pub@mnhn.fr / https://sciencepress.mnhn.f

Académie des sciences, Institut de France, 23 quai de Conti, 75006 Paris.

(C) Publications scientifiques du Muséum national d'Histoire naturelle / C Académie des sciences, Paris, 2021

ISSN (imprimé / print): 1631-0683/ ISSN (électronique / electronic): 1777-571X 


\title{
Prolagus Pomel, 1853 (Lagomorpha, Mammalia) in the framework of the Pliocene faunal rearrangements in central Europe
}

\author{
Stanislav ČERMÁK \\ Institute of Geology of the Czech Academy of Sciences, \\ Rozvojová 269, 16500 Prague 6 (Czech Republic) \\ cermaks@gli.cas.cz (corresponding author)
}

Chiara ANGELONE

Department of Sciences, University Roma Tre, Largo S. L. Murialdo 1, 00146 Roma (Italy)

and Institut Català de Paleontologia Miquel Crusafont, Edifici Z ICTA-ICP, Carrer de les Columnes s/n, Campus de la Universitat Autònoma de Barcelona,

08193 Cerdanyola del Vallès, Barcelona (Spain)

Blanca MONCUNILL-SOLÉ

Centro de Investigacións Científicas Avanzadas (CICA), As Caballeiras s/n,

Campus de Elviña, Universidade da Coruña, 15071 A Coruña (Spain)

and Department of Sciences, University Roma Tre, Largo S. L. Murialdo 1, 00146 Roma (Italy)

Submitted on 21 February 2020 | Accepted on 25 May 2020 | Published on 28 June 2021

urn:Isid:zoobank.org:pub:4FD1B8AF-7957-469E-A627-8126691743C3

Čermák S., Angelone C. \& Moncunill-Solé B. 2021. - Prolagus Pomel, 1853 (Lagomorpha, Mammalia) in the framework of the Pliocene faunal rearrangements in central Europe. Comptes Rendus Palevol 20 (28): 597-617. https://doi.org/10.5852/cr-palevol2021v20a28

\section{ABSTRACT}

Pliocene occurrences of Prolagus Pomel, 1853 in central Europe represent anomalies out of the peri-Mediterranean area, at that time the core distribution of the genus. Though known for several decades, those materials never underwent a general revision. The detailed analysis and comparison of all available materials performed here revealed two phenotypic entities: 1) Prolagus bilobus Heller, 1936 (Gundersheim localities, Raciszyn 1), for which were defined additional diagnostic characters and ontogenetic patterns of variation (d3/p3 and mandible); and 2) Prolagus sp. (Beremend 26/39), probably a new species. All the available occurrences are dated to MN15b. The morphological trends towards the reduction of $\mathrm{p} 3$ entoconid and of enamel folding evidenced in Pliocene Prolagus of western Europe cannot be recognized in coeval central European forms. Evidently, P. bilobus and Prolagus sp. do not pertain to the western European clade, whose separation is known since the early late Miocene.

KEY WORDS Prolagidae,

Prolagus bilobus,

Gundersheim, Raciszyn 1, palaeobiogeography. We hypothesize that at least $P$. bilobus originated from a dispersal of Prolagus from south-eastern regions of Europe rather than from an autochthonous speciation of isolated populations left as a relict after the southward displacement of Prolagus distribution area. The dispersal is likely to be related to the Pliocene global environmental changes during which extensive faunal rearrangements took place in Europe, in particular to those near the early/late Pliocene boundary. 


\author{
MOTS CLÉS \\ Prolagidae \\ Prolagus bilobus, \\ Gundersheim, \\ Raciszyn 1 \\ Beremend, \\ paléobiogéographie.
}

\section{RÉSUMÉ}

Prolagus Pomel, 1853 (Lagomorpha, Mammalia) dans le cadre des réarrangements fauniques du Pliocène de l'Europe centrale.

Le peu de données dont nous disposons sur le Prolagus Pomel, 1853 du Pliocène d'Europe centrale représentent des anomalies dans la distribution géographique du genre, qui, à cette époque, est limité à la zone péri-Méditerranéenne. Bien que la présence de Prolagus dans le Pliocène d'Europe centrale est connue depuis plusieurs décennies, de tels matériels n'ont jamais fait l'objet d'une révision générale. Une analyse détaillée et une comparaison de tous les matériels disponibles étudiés ici ont permis d'identifier deux éntités phénotypiques : 1) Prolagus bilobus Heller, 1936 à Gundersheim (plusieurs localités) et Raciszyn 1, pour lequel des caractères diagnostiques additionnels et des modèles ontogénétiques de variation (d3/p3 et mandibule) ont été définis; et 2) Prolagus sp. à Beremend 26/39, qui représente probablement une nouvelle espèce. Toutes les occurrences disponibles sont datées du MN15b. Les tendances morphologiques vers une réduction de l'entoconide de $\mathrm{p} 3$ et une diminution du repli de l'émail, mises en évidence dans les espèces pliocènes de Prolagus d'Europe occidentale, n'ont pas été reconnues dans des formes contemporaines d'Europe centrale. Prolagus bilobus et Prolagus sp. n'appartiennent manifestement pas au clade ouest-européen, dont la séparation est connue depuis le début du Miocène supérieur. Notre hypothèse est qu'au moins $P$. bilobus trouve son origine dans une dispersion des populations à partir de l'Europe sud-orientale plutôt que, comme on le croyait autrefois, dans une spéciation autochtone de populations isolées, laissées telles des vestiges à la suite du déplacement vers le sud de l'aire de distribution géographique de Prolagus. Cette dispersion est probablement liée aux changements environnementaux à l'échelle globale survenus au Pliocène, et responsables de changements environnementaux globaux pendant lesquels des réarrangements fauniques majeurs ont pris place en Europe, et particulièrement à la transition Pliocène inférieur/supérieur.

\section{INTRODUCTION}

Prolagus Pomel, 1853 represents a successful, long-lasting, species-rich lagomorph genus that during most of the Miocene was widely distributed throughout Europe and formed a significant part of the small mammal assemblages (López Martínez 1974, 1989, 2001). Probably, since the latest Miocene, its geographical range started to dwindle. The Pliocene is a critical moment in the evolution of Prolagus. The changes in its palaeobiogeographical distribution from pan-European to patchy and mainly peri-Mediterranean distribution become evident in this period. The Pliocene record of Prolagus in the peri-Mediterranean area is quite common and well documented, in contrast to central Europe, where the genus is very rare and occurs sporadically in a few localities.

Isolated Pliocene populations of Prolagus in central Europe have been known since the early 20th century (Heller 1936). The proven occurences of the genus have been limited until now to Prolagus bilobus Heller, 1936 documented from Gundersheim sites (MN15b) in Germany and Raciszyn 1 (MN15b) in Poland (Heller 1936; Fejfar \& Storch 1990; Fejfar et al. 2006; Fostowicz-Frelik 2010; Čermák \& Angelone 2013). Apart from punctual taxonomic disputes (cfr. Fostowicz-Frelik 2010 vs Čermák \& Angelone 2013), these remains have never been the subject of a detailed, dedicated study.

Some studies exist about the taxonomy and phylogeny of Pliocene Prolagus from western Europe (López Martínez \& Thaler 1975; López Martínez 1989; Angelone 2008a), and as well, some enigmatic isolated remains have been reported from eastern Europe (Agadjanian \& Erbajeva 1983; Erbajeva \&
Shushpanov 1988; Averianov \& Tesakov 1998; Tesakov \& Averianov 2002).

We decided to focus our attention to Pliocene central European Prolagus, in order to summarize the available materials, to clarify their taxonomic status, and to try to unravel the reasons that led to the palaeobiogeographical distribution observed after the Miocene.

\section{THE LOCALITIES: HISTORICAL BACKGROUND AND GEOLOGICAL SETTING}

The Pliocene record of Prolagus in Central Europe is limited to the following localities; their geographical locations are shown in Figure 1.

\section{GUNDERSHEIM}

Most of the fossil faunas at Gundersheim (Alzey-Worms district, Rheinland-Pfalz, Germany) come from three quarries, located SW from the homonymous village. A study of the fossil record from Gundersheim was first performed by Heller (1936). However, although the material originated from several fissures of quarries, F. Heller published the different faunas considering them as one assemblage, with only sporadic notes concerning their original provenance. Thus, the exact location, age, and name of each site/assemblage have since then remained unclear. Until the 1960s, all the samples were generally considered as pertaining to one faunal unit, and referred to simply as "Gundersheim". Eventually, Kretzoi (1962) distinguished two faunal units in Heller's original material: an older 


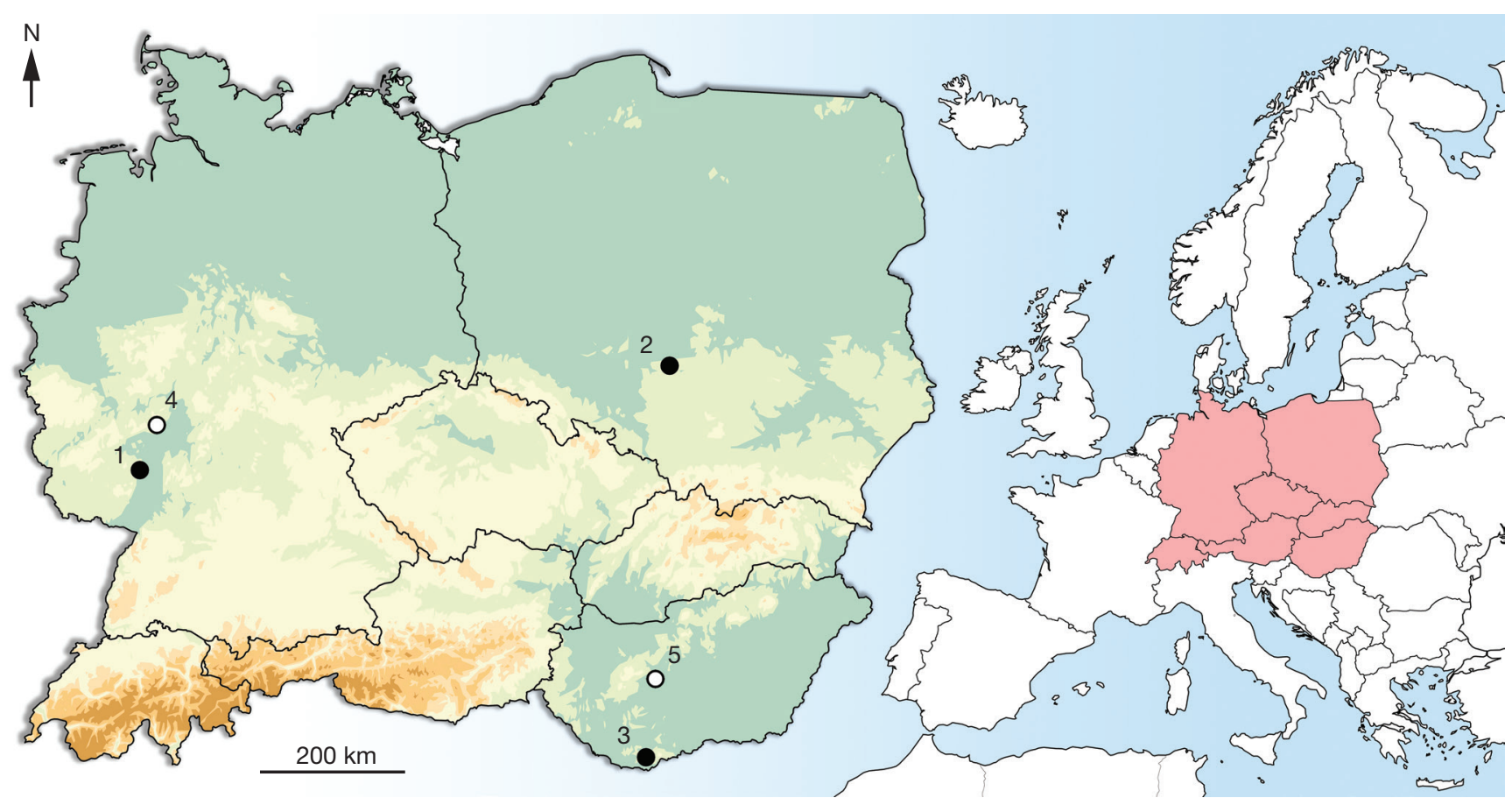

FIG. 1. - Geographical localization of Pliocene Prolagus-bearing localities in central Europe: 1, Gundersheim 1 (sensu Tobien 1980; age uncertain, most likely MN15b), Gundersheim-Findling (MN15b), Gundersheim-fissure 4 (MN15b); 2, Raciszyn 1 (MN15b); 3, Beremend 26 and 39 (MN15b); 4, Wölfersheim (MN15b); 5, Kisláng (Prolagus age uncertain, most likely MN15b). Black circles, available and studied material; white circles, unavailable material mentioned in literature (not figured, nor described).

one, correlated with the Csarnotanian (sensu Kretzoi 1962; c. MN15b), called Gundersheim 1 by Tobien (1980), and a younger one, correlated with the late Villányian (sensu Kretzoi 1962; c. MN17), called Gundersheim 2 by Tobien (1980).

Tobien (1980) also numbered particular Gundersheim fissures. Since the 1950s, he discovered and studied 22 fissures of which five yielded identifiable faunal remains. The most interesting was fissure no. 4 , in which were recovered Trilophomys schaubi, Bjoernkurtenia canterranensis, Baranomys longidens, Germanomys weileri, and Mimomys gracilis, which indicate a late Ruscinian age (MN15b). This site, published in detail by Fejfar et al. (2006), is known as Gundersheimfissure 4 (Gundersheim 3 sensu Koenigswald \& Tobien 1990). Tobien (1980) assumed that the most of Heller's older faunal unit (Gundersheim 1) most likely originated from this fissure.

The last fauna at Gundersheim was discovered in 1976 in an isolated block of calcified red loam found in the open field near the Rosengartenbruch quarry. The locality, known as Gundersheim-Findling (Gundersheim 4 sensu Koenigswald \& Tobien 1990), yielded a faunal assemblage analogous to the one found in Gundersheim-fissure 4 described by Fejfar et al. (2006), and indicating a late Ruscinian (MN15b) age as well. Rodents from this locality were described in detail by Fejfar \& Storch (1990), insectivores by Dahlmann \& Storch (1996), and prolagid lagomorphs partly by Čermák \& Angelone (2013).

Apart from Prolagus, herein studied, Gundersheim localities yielded other lagomorph taxa: Gundersheim-Findling Pliopentalagus dietrichi (Fejfar, 1961) published in detail by
Čermák \& Wagner (2013) and Hypolagus petenyii Čermák \& Fladerer in Čermák, 2009 (p3 dex [morphotype I/a/A], 2 lower molariforms); Gundersheim-fissure 4 - Leporidae gen. et sp. indet. (fragmentary lower molariform); and "Hasenfundstelle I" (after label by Heller) - Hypolagus published by Heller (1936: 137-139; figs 1-2, pl. XI: 13-14) as H. brachygnathus and reassigned here as $H$. cf. brachygnathus (Kormos, 1930) (2 mandibles - sin with p3-p4 [morphotype II/c/D] and dex with p3 $[(\mathrm{I} / \mathrm{II}) / \mathrm{c} / \mathrm{C}])$.

\section{RACISZYN 1}

The locality Raciszyn 1 corresponds to a small abandoned quarry located $c .500 \mathrm{~m} \mathrm{~W}$ from the village of Raciszyn (district Gmina Działoszyn, province Łódź, central Poland). The fossil material comes from the terra rossa filling of a collapsed cave formed in Oxfordian limestones. Preliminary information about the locality and its fauna was provided by Kowalski (1990), Nadachowski (1990), Sulimski \& Szynkiewicz (1994), Szynkiewicz \& Jagiełło (2015), and Nadachowski et al. (2015). The locality yielded a fossil assemblage consisting of about 40 mammalian taxa (Sulimski in Szynkiewicz \& Jagiełło 2015). The assemblage includes biostratigraphically valuable taxa such as a small Mimomys of the gracilis-stehlini lineage (with prevalence of primitive forms), Mimomys hassiacus, Baranomys or Trilophomys (Nadachowski 1990; Szynkiewicz \& Jagiełło 2015; Nadachowski et al. 2015), indicating a late Ruscinian (MN15b) age (Kowalski 1990; Nadachowski et al. 2015). The remains of Prolagus addressed in this paper were first studied by Fostowicz-Frelik (2010) and described as a new species, Prolagus 
osmolskae Fostowicz-Frelik, 2010. Eventually, Čermák \& Angelone (2013) revised and synonymized the species with Prolagus bilobus. The only other lagomorph species found in Raciszyn 1 is Hypolagus petenyii (Nadachowski et al. 2015).

\section{BEREMEND}

The limestone quarry at Beremend is situated in the westernmost part of the Villány Hills (Baranya region, Hungary), an area palaeontologically investigated since the half of the $19^{\text {th }}$ century. The first fossiliferous fissures in the quarry were discovered by S. J. Petényi in 1847 (Petényi 1864; Kordos 1991). During the $20^{\text {th }}$ century, the quarry yielded several dozens of vertebrate-bearing sites, whose age span from the early Pliocene to the early Pleistocene (see Kretzoi 1956, 1959, 1962; Jánossy 1986; Kordos 1991; Pongrácz 1999; Császár \& Kordos 2004 for details). The material, comprising remains of the genus Prolagus studied herein, was collected by L. Pongrácz from fissure fillings Beremend 26 and 39. The site no. 26 yielded a very extensive and diverse fossil assemblage of mammals including the biostratigraphical markers Mimomys gracilis, Dolomys nehringi, and Propliomys hungaricus (cf. Császár \& Kordos 2004; Čermák 2007; Čermák unpubl. data). Such taxa indicate a late Ruscinian (MN15b) age for Beremend 26, i.e., slightly younger than Csarnóta 2 (L. Kordos pers. comm.). Apart from Prolagus, the locality yielded also other lagomorphs, namely Ochotonoma csarnotana Kretzoi, 1959 (partly studied by SČ; see Čermák 2007) and Hypolagus petenyii.

In comparison with Beremend 26, the fossil record from Beremend 39 is much scantier and less diverse, consisting of "only" about 15 mammalian taxa (Pongrácz in litt.; Čermák \& Wagner 2013). Nevertheless, the presence of Beremendia fissidens, Eliomys intermedius, M. cf. gracilis, Propliomys hungaricus, $H$. petenyii, and Trischizolagus dumitrescuae, together with the evolutionary degree of the arvicolids, indicate also a late Ruscinian (MN15b) age, analogous to Beremend 26 (Čermák \& Wagner 2013).

\section{OTHER LOCALITIES}

In addition to the above mentioned localities, there are other two relevant sites from which the presence of Prolagus was reported. Unfortunately, however, we were not successful to track down the lagomorph material from those localities. The taxonomic position of those samples remained thus unclear.

- Wölfersheim (Wetterau district, Germany; MN15b) - the occurrence of P. bilobus in this locality was reported in a faunal list by Tobien (1977). Dahlmann (2001) studied in detail small mammals from this locality, but not lagomorphs, which were reported only in a faunal list (ibid:: 95) with reference to Tobien's list (1977). The collection of mammals from Wölfersheim is deposited in the SMF, but lagomorphs are missing.

- Kisláng (Polgárdi district, Hungary; MN15 or MN17 according to Mayhew 2012) - Kretzoi (1954) reports from this locality a sole left $\mathrm{p} 3$ of Prolagus. Based on the presence of the crochet ("Der Sporn am Mittelgraben der Kauflache"), Kretzoi (1954: 247) hypothesized a taxonomic proximity of the Kisláng specimen to Prolagus from Gundersheim, and referred to it as $P$. cf. bilobus. The material of Kisláng collected and described by Kretzoi (1954) is currently curated in the collection of the MFGI, but the last surveys (SČ in 2005) were not successful to track down the specimen. At any rate, the Kisláng mammalian assemblage is a mixture of material of different geological ages with a minimum estimated range between $c$. 1.7-3.5 Ma (Mayhew 2012). Thus, the age of the p3 reported by Kretzoi (1954) is unclear. Nevertheless, considering the presence of Mimomys $\mathrm{cf}$. hassiacus in the locality (Mayhew 2012), the late Ruscinian (MN15b) age cannot be excluded (see for details Čermák \& Angelone 2013).

\section{MATERIAL AND METHODS}

All the material from the Gundersheim localities is stored in the collections of the SMF and the material from Raciszyn 1 is curated in the collections of the ZPAL. The material from Beremend 26 and 39 comes from the private collection of L. Pongrácz (Győr, Hungary) and is temporarily housed in the collection of the GLI. Following Čermák \& Angelone (2013), we used Gundersheim 1 and Gundersheim 2 for Heller's original localities/assemblages (sensu Tobien 1980), and Gundersheimfissure 4 and Gundersheim-Findling for localities published by Fejfar et al. (2006) and Fejfar \& Storch (1990).

For teeth nomenclature and metrics we follow López Martínez (1989) and Angelone \& Sesé (2009), for jaws we follow Wible (2007) and Cermák (2009). Drawings and measures were taken with the aid of a Dino-Lite digital microscope and of a binocular microscope with ocular micrometer. Dental measurements were taken as maximum antero-posterior or bucco-lingual dimensions of the respective two-dimensional dental structures orthogonal to prismatic shaft. For consistency, only adult specimens (recognized by their prismatic tooth shape) were used for interspecific size comparisons. All measured data are given in millimeters [mm].

The biostratigraphic terminology used in this paper follows Fejfar \& Heinrich (1983) and Fejfar et al. (1998). The term "Central Europe" is understood here as a geographic region in the center of Europe including Germany, Switzerland, Liechtenstein, Austria, Poland, the Czech Republic, Slovakia, and Hungary. Country abbreviations follow ISO 3166-1 alpha-2 codes. Following the recommendations of the International Commission of Stratigraphy, the first letter of informal subepochs is not capitalized.

Interspecific comparisons were made with the early Miocene to Pleistocene European species of Prolagus using original or additional materials (indicated by “*”), or on a bibliographical basis (unless otherwise stated, data were taken from the original descriptions of species): ${ }^{*}$ P. oeningensis (König, 1825); ${ }^{*}$ P. sardus (Wagner, 1829); P. vasconiensis Viret in Roman \& Viret, 1930; *P. savagei Berzi, 1967; *P. crusafonti López Martínez in López Martínez \& Thaler, 1975; P. depereti López Martínez in López Martínez \& Thaler, 1975 ; * P. figaro López Martínez in López Martínez \& Thaler, $1975 ;{ }^{*}$ P. ibericus López Martínez in López Martínez \& Thaler, 1975; *P. michauxi López Martínez in López Martínez \& Thaler, $1975 ;{ }^{*}$ P. tobieni López in López Martínez et al., 1977; * P. sorbinii Masini, 1989; P. fortis López 
Martínez \& Sesé in Álvarez-Sierra et al., 1990; P. caucasicus Averianov \& Tesakov, 1998; *P. italicus Angelone, 2008a; *P. latiuncinatus Angelone \& Čermák, 2015; and *P. pannonicus Angelone \& Čermák, 2015. Other metric data were taken from Álvarez-Sierra et al. (1990), Tesakov \& Averianov (2002), and Angelone \& Veitschegger (2015).

\section{ABBREVIATIONS}

\section{Institutions}

GLI Institute of Geology of the Czech Academy of Sciences, Prague;

MFGI Magyar Földtani és Geofizikai Intézet [Hungarian Institute of Geology and Geophysics], Budapest;

SMF Senckenberg Museum, Frankfurt;

ZPAL Institute of Palaeobiology, Polish Academy of Sciences, Warszawa.

\section{Teeth}

D/d Upper/lower deciduous teeth;

I/i Upper and lower incisors;

$\mathrm{M} / \mathrm{m} \quad$ Upper/lower molar;

$\mathrm{P} / \mathrm{p} \quad$ Upper/lower premolar.

\section{Measurements}

AA Partial width;

L Length;

Ltrig Trigonid length;

$\mathrm{PH} \quad$ Hypoflexus width;

TH Distal hyperloph length;

W Width;

Wtl Third lobe width of $\mathrm{m} 2$;

Wtal Talonid width;

Wtrig Trigonid width.

\section{Other abbreviations}

$\mathrm{D}_{\mathrm{p}-\mathrm{d}} \quad(\mathrm{L}$ of d3)-(L of p3) [mm];

$\mathrm{K}_{\mathrm{d} / \mathrm{p}} \quad\left((\mathrm{L} \text { of d3)/(L of p3) })^{*} 100[\%]\right.$;

$\mathrm{M}_{\mathrm{dL}} \quad((\mathrm{L} \text { of alveolar row }) /(\mathrm{L} \text { of diastema }))^{*} 100[\%]$;

$\mathrm{M}_{\mathrm{H}} \quad(((\mathrm{H}$ of mandible at $\mathrm{p} 3+\mathrm{H}$ of mandible at $\mathrm{m} 2) / 2) /$

$\mathrm{L}$ of alveolar row)*100 [\%];

N Number of specimens;

OR Observed range;

$\overline{\mathrm{X}} \quad$ Arithmetic mean.

\section{SYSTEMATIC PALAEONTOLOGY}

Class MAMMALIA Linnaeus, 1758

Order LAGOMORPHA Brandt, 1855

Family Prolagidae Gureev, 1960

Genus Prolagus Pomel, 1853

Prolagus bilobus Heller, 1936

(Figs 2-4)

NAME-BEARING TYPE AND TYPE LOCALITY. - Lectotype - left p3 (SMF 1996/136), illustrated in Heller (1936: fig. 3), designed by López
Martínez \& Thaler (1975), revised by Čermák \& Angelone (2013). Gundersheim (probably Gundersheim 1 sensu Tobien 1980; age uncertain, most likely MN15b), Rheinland-Pfalz, Germany (see Čermák \& Angelone 2013 for details).

EMENDED DiAGNOSIS. — See Čermák \& Angelone (2013: 49).

MATERIAL. - Gundersheim (probably Gundersheim 1, original material of F. Heller, partly published in Heller [1936]): 1 p3 sin, SMF 1996/136; 1 fragment of mandibular body dex with p4-m2, SMF 1994/895; 1 talonid of p4 dex, SMF 1994/896; 1 talonid of p4 or m1 dex, SMF 1994/897; 1 trigonid of p4 or m1 dex, SMF 1996/137; 1 mandibular body dex with p4-m2, SMF 1996/156; 1 mandibular ramus dex with articular head, SMF 1996/157; 1 mandibular ramus dex with p4-m1, SMF 1996/158. Gundersheimfissure 4 (material published by Fejfar et al. 2006): 2 P2 sin, SMF 2005/1, 2; 1 P3 sin, SMF 2005/3; 1 d3 dex, SMF 2005/4; 1 p3 sin, SMF 2005/5; 1 fragment of mandibular body dex, SMF 2005/6. Gundersheim-Findling: 11 I1 sin, SMF 1985/171-181; 6 I1 dex, SMF 1985/182-187; 2 P2 sin, SMF 1985/70, 71; 5 P2 dex, SMF 1985/72-76; 5 P3 sin, SMF 1985/77, 80, 82, 84, 85; 7 P3 dex, SMF 1985/78, 79, 81, 83, 86-88; 8 P4 sin, SMF 1985/89-96; 12 P4 dex, SMF 1985/97-108; 1 fragment of P4 sin, SMF 1985/242; 4 fragments of P4 dex, SMF 1985/240, 241, 243, 244; 9 M1 sin, SMF 1985/109-112, 115, 124, 126, 247, 248; 17 M1 dex, SMF 1985/113, 114; 116-123, 125, 141, 142, 245, 246, 249, 255; 4 M2 sin, SMF 1985/129, 133, 135, 140; 12 M2 dex, SMF 1985/127, $128,130-132,134,136-139,178,179 ; 3$ enamel fragments of upper molariforms, SMF 1985/252-254; 6 fragments of mandibular bodies dex with various teeth, SMF 1985/165-170; 1 i1 sin, SMF 1985/188; 6 p3 sin, SMF 1985/144-146, 160, 161, 163; 11 p3 dex, SMF 1985/143, 147-153, 159, 162, 164; 5 fragments of p3, SMF 1985/154-158; 9 p4/m1 sin, SMF 1985/189-196, 234; 6 p4/m1 dex, SMF 1985/215-220; 6 trigonids of $\mathrm{p} 4 / \mathrm{m} 1$ sin, SMF $1985 / 204-206$, 209, 223, 235; 4 trigonids of p4/m1 dex, SMF 1985/221, 225, 236, 237; 3 talonids of p 4/m1 sin, SMF 1985/207, 208, 238; 2 talonids of p4/m1 dex, SMF 1985/222, 224; $1 \mathrm{~m} 2$ sin, SMF 1985/210; $1 \mathrm{~m} 2$ dex, SMF 1985/226; 1 trigonid of $\mathrm{m} 2$ sin, SMF 1985/211; 1 trigonid of $\mathrm{m} 2$ dex, SMF 1985/228; 3 talonids of $\mathrm{m} 2$ sin, SMF 1985/212-214; 4 talonids of $\mathrm{m} 2 \mathrm{dex}$, SMF 1985/227, 229, 230, 239; 2 ?m 2 sin, SMF 1985/232, 233; 2 D3/4 sin, SMF 1985/268, 269; 2 d3 sin, SMF 1985/256, 257; 5 d3 dex, SMF 1985/258-262; 4 d4 sin, SMF 1985/263-266; 1 d4 dex, SMF 1985/267. Raciszyn 1: 1 mandible body dex with complete dentition, ZPAL M.10.

Measurements. - See Tables 1 and 2, Fejfar et al. (2006), and Čermák \& Angelone (2013).

StRATIGRAPHIC AND GEOGRAPHIC DISTRIBUTION. - Early Pliocene (late Ruscinian, MN15b) of central Europe: localities Gundersheim (probably Gundersheim 1 sensu Tobien 1980; original material of F. Heller), Gundersheim-fissure 4, Gundersheim-Findling, possibly Wölfersheim (all in Germany) and Raciszyn 1 (Poland).

\section{DESCRIPTION}

d3 (Fig. 2A, B)

Three-lobed tooth; the anteroconid is always isolated $(\mathrm{N}=7)$, shaped as an elongated triangle; it may bear an anterior and/or posterior undulation in the lingual side; in one case there is a connection of the anteroconid and the accessory cusp, marked by a deep anteroflexid. A small, roundish cusp is present in the antero-lingual side, between anteroconid and protoflexid, in $86 \%$ of cases $(\mathrm{N}=7)$. The trigonid is indented by an average-sized to deep centroflexid; the protoconulid is quite reduced, as well as the metaconid. A centroisthmus between trigonid and talonid is present in $40 \%$ of cases $(\mathrm{N}=5)$. In 
TABLE 1. - Dental measurements of Prolagus bilobus Heller, 1936 from the early Pliocene (MN15b) locality Gundersheim-Findling. See Material and methods for abbreviations.

\begin{tabular}{|c|c|c|c|c|c|}
\hline \multicolumn{6}{|c|}{ Lower and upper teeth } \\
\hline & & $\mathrm{N}$ & $\overline{\mathrm{X}}$ & OR & $\mathrm{CV}$ \\
\hline \multirow[t]{2}{*}{ p3 } & $\mathrm{L}$ & 10 & 2.47 & $2.20-2.77$ & 7.96 \\
\hline & W & 9 & 2.30 & $2.11-2.57$ & 6.34 \\
\hline \multirow[t]{4}{*}{$\mathrm{p} 4 / \mathrm{m} 1$} & $\mathrm{~L}$ & 13 & 1.95 & $1.69-2.13$ & 7.11 \\
\hline & Ltrig & 22 & 1.12 & $0.90-1.32$ & 9.41 \\
\hline & Wtrig & 23 & 2.13 & $1.88-2.47$ & 8.64 \\
\hline & Wtal & 19 & 2.09 & $1.85-2.39$ & 7.73 \\
\hline \multirow[t]{4}{*}{ m2 } & L & 3 & 2.65 & $2.45-2.81$ & - \\
\hline & Wtrig & 6 & 2.02 & $1.71-2.19$ & 9.09 \\
\hline & Wtal & 7 & 1.99 & $1.82-2.25$ & 7.36 \\
\hline & Wtl & 7 & 1.38 & $1.26-1.54$ & 8.46 \\
\hline \multirow[t]{2}{*}{ d3 } & L & 5 & 1.37 & $1.07-1.50$ & 12.84 \\
\hline & $\mathrm{W}$ & 5 & 1.06 & $0.96-1.14$ & 7.27 \\
\hline \multirow[t]{3}{*}{ d4 } & $\mathrm{L}$ & 5 & 1.50 & $1.29-1.79$ & 12.30 \\
\hline & Wtrig & 5 & 1.12 & $1.00-1.21$ & 7.94 \\
\hline & Wtal & 5 & 1.16 & $1.05-1.25$ & 6.88 \\
\hline \multirow[t]{2}{*}{ P2 } & $\mathrm{L}$ & 5 & 1.69 & $1.60-1.82$ & 5.52 \\
\hline & $\mathrm{W}$ & 5 & 2.64 & $2.50-2.87$ & 6.97 \\
\hline \multirow[t]{3}{*}{ P3 } & $\mathrm{L}$ & 10 & 2.04 & $1.71-2.21$ & 7.06 \\
\hline & W & 9 & 3.45 & $2.85-3.84$ & 8.92 \\
\hline & $\mathrm{AA}$ & 9 & 2.36 & $1.70-2.76$ & 12.77 \\
\hline \multirow[t]{5}{*}{ P4 } & $\mathrm{L}$ & 16 & 1.65 & $1.36-1.85$ & 8.73 \\
\hline & TH & 17 & 0.98 & $0.80-1.17$ & 10.79 \\
\hline & W & 11 & 3.23 & $2.79-3.80$ & 9.98 \\
\hline & $\mathrm{AA}$ & 11 & 2.87 & $2.42-3.31$ & 11.01 \\
\hline & $\mathrm{PH}$ & 12 & 1.45 & $1.19-1.69$ & 11.61 \\
\hline \multirow[t]{4}{*}{ M1 } & $\mathrm{L}$ & 19 & 1.66 & $1.12-1.95$ & 13.64 \\
\hline & $\bar{W}$ & 18 & 3.07 & $2.30-3.51$ & 12.39 \\
\hline & $A A$ & 19 & 2.70 & $1.94-3.04$ & 11.76 \\
\hline & $\mathrm{PH}$ & 19 & 2.42 & $1.70-2.90$ & 12.70 \\
\hline \multirow[t]{4}{*}{ M2 } & $\mathrm{L}$ & 13 & 1.51 & $1.25-1.80$ & 11.03 \\
\hline & W & 12 & 2.84 & $2.29-3.54$ & 13.32 \\
\hline & $\mathrm{AA}$ & 13 & 2.44 & $1.94-2.98$ & 13.33 \\
\hline & $\mathrm{PH}$ & 13 & 2.21 & $1.80-2.69$ & 12.99 \\
\hline \multirow[t]{2}{*}{ D3/4 } & $\mathrm{L}$ & 2 & - & $1.21,1.29$ & - \\
\hline & W & 2 & - & $1.75,1.96$ & - \\
\hline
\end{tabular}

the talonid, the entoconid is much smaller than the globous hypoconid, which appears to be the largest cusp, sometimes even larger than the anteroconid.

\section{d4 (Fig. 2C, D)}

Trigonid and talonid are always well separated. The trigonid is of equal size or slightly smaller than the talonid; it bears a quite developed, flattened anterior lobe, separated from the main body of the trigonid by a simple, straight paraflexid (no centroflexid). The triangular talonid lacks or has a very reduced anterior isthmus.

\section{p3 (Fig. 2E [in part], F-N)}

The occlusal features of adult teeth (identified mainly by their prismatic shaft) are the following: large size; the anteroconid is as large as metaconid $(92 \%, \mathrm{~N}=12)$ - in one case, it is slightly smaller; the anteroconid is roughly shaped as a rightangled triangle and appears "tilted" (i.e., with the $90^{\circ}$ angle pointing posteriorly); the main body of the anteroconid is always displaced towards the lingual side $(\mathrm{N}=13)$, its posterior and labial sides with undulation or notch in $69 \%(\mathrm{~N}=13)$; the metaconid is quadrangular, with enamel undulated and/ or crenulated all around; the crenulation may interest also the anterior side of the entoconid, which is always quite thick (length $>1 / 5$ of total $\mathrm{L} ; \mathrm{N}=11$ ) and without enamel hiatus; the mesoflexid is very variable, from relatively short and U-shaped to quite long and J-shaped $(\mathrm{N}=12)$ - in one case, the mesoflexid connects to the centroflexid, isolating the metaconid, and in 2 cases it hosts an additional enamel islet in its lingual side (such islet in one case connects to the entoconid with wear, in the other case it remains isolated); the crochet is present in all adult specimens, predominantly with a very large size (in 50\%; large in 36\%, small in 14\%; $\mathrm{N}=14)$; the centroflexid has undulated sides $(71 \%, \mathrm{~N}=$ 14 ), parallel in $3 / 4$ of its length, then widens in correspondence of the crochet - apart for the sporadical above mentioned connection with the mesoflexid, the centroflexid may be anteriorly "closed" by a connection of proto- and metaconid; the metaisthmus varies from relatively wide (2 cases) to very thin $(\mathrm{N}=14)$, when it is thin, it may have a bottlenecked appearance; the protoisthmus is always thin to very thin $(\mathrm{N}=13)$ and its connection with the protoconid has a "bottlenecked" appearance only in $23 \%(\mathrm{~N}=13)$; the hypoconid is triangular in shape and predominantly of average size (only in two cases it is quite large); the hypoflexid is very deep, almost reaching the posterior side of the tooth; the anterior part of the protoconid is quite protruding lingually, and the passage to the thin posterior part is marked by an abrupt narrowing; the protoconid is connected to the protoconulid by a wide to very wide loph, at the junction protoconid-protoconulid there may be a spur in about half of the cases; the protoconulid is quite short, often very wide with a bulky appearance.

The occlusal features of juvenile teeth (identified mainly by their conical shaft; $\mathrm{N}=6$ ) are the following: the anteroconid, always displaced towards the lingual side, is medium-sized (smaller than metaconid in 67\%), rather flattened oval in shape, distally smooth (in one case lingually with fold); the metaconid is mainly triangular, in one case is isolated; the crochet may be absent (1 case), very reduced or of average size, straight or inclined with respect to the antero-posterior axis of the tooth, and its position also varies from central to displaced (there is no univocal correspondence between its size, shape and position); the hypoconid is large compared to the size of the tooth, triangular or with rounded lingual edge; the hypoflexid is deep, as in adult individuals; the mesoflexid is predominantly $\mathrm{V}$-shaped and short; the centroflexid shape is similar to that of adults, with undulated sides in 33\%; the protoisthmus is thin to very thin, often bottlenecked (50\%); the metaisthmus varies from thin to average wide; the protoconid has the same shape as in adults (developed anteriorly, reduced posteriorly), however the anterior part may be more or less developed towards the lingual side; the proportions protoconid-protoconulid are variable, but in general the protoconulid is usually thin, though not very long.

\section{p4-m2 (Fig. 2E [in part], O)}

The p4-m1 consist of two separate lobes of approximately similar width fused together by cement; posteriorly, both 


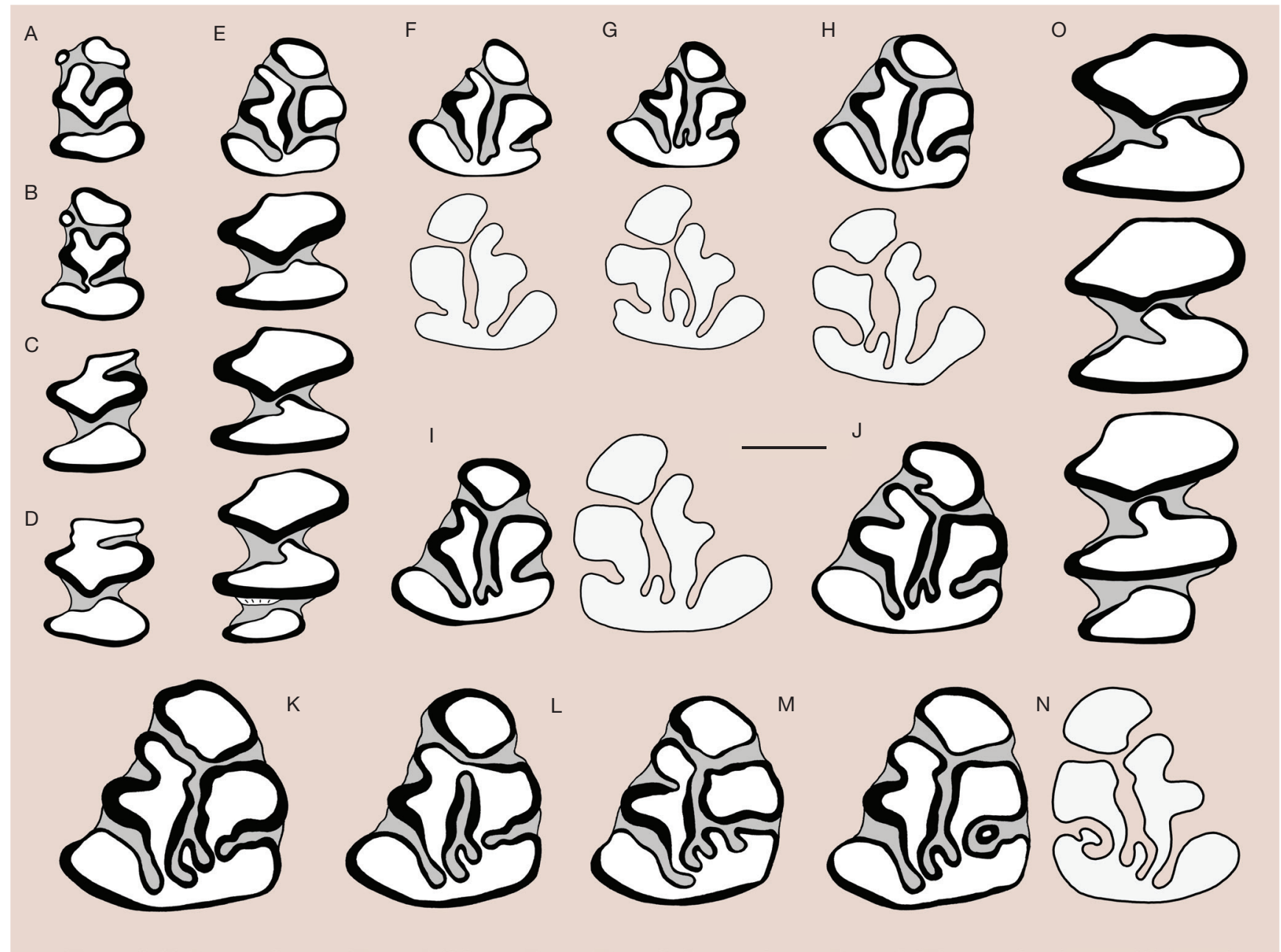

FIG. 2. - Morphology of lower teeth of Prolagus bilobus Heller, 1936 from the early Pliocene (MN15b) locality Gundersheim-Findling: A, left d3, occlusal view, SMF 1985/256; B, right d3, occlusal view, reversed, SMF 1985/259; C, left d4, occlusal view, SMF 1985/264; D, right d4, occlusal view, reversed, SMF 1985/267; E, right p3-m2, occlusal view, reversed, SMF 1985/165; F, right p3, occlusal and root views, reversed, SMF 1985/152; G, right p3, occlusal and root views, reversed, SMF 1985/151; H, right p3, occlusal and root views, reversed, SMF 1985/150; I, left p3, occlusal and root views, SMF 1985/145; J, right p3, occlusal view, reversed, SMF 1985/147; K, right p3, occlusal view, reversed, SMF 1985/159; L, right p3, occlusal view, reversed, SMF 1985/162; M, right p3, occlusal view, reversed, SMF 1985/164; N, left p3, occlusal and root views, SMF 1985/163; O, right p4-m2, occlusal view, reversed, SMF 1985/166. Scale bar: 1 mm.

lobes have thickened enamel. The trigonids are of rhomboid shape, longer than talonids, with an accentuated anterior step; the talonid shows an antero-labial flexid, and a shallow notch in the labial edge; the $\mathrm{m} 2$ are three-lobed, the first two similar to p4-m1, whereas the last lobe is simple, triangular-shaped.

\section{Lower jaw (Fig. 4)}

Eleven fragments of mandibular bodies in different ontogenetic stages are available. In adult individuals, the mandible is rather robust. The diastema is long, but slightly shorter than the p3-m2 alveolar row (Table 2). The posterior mental foramen is large, oval, located close to the ventral edge of the mandibular body below $\mathrm{m} 1$ (in most cases, below the trigonid/talonid connection; $c .67 \%, \mathrm{~N}=6$ ), and remarkably maintains the same position both in juvenile and adult specimens. The area below p3-p4 is richly fenestrated. The lower incisor extends below the $\mathrm{p} 4$ (in most cases below the trigo$\mathrm{nid} /$ talonid connection; $c .50 \%, \mathrm{~N}=6$ ). The ventral margin of the mandible is convex, and becomes more prominent and angular with increasing ontogenetic age. The mylohyoid line is moderately developed, and in ventral view it appears located near the buccal edge of the mandibular body. The coronoid process is weakly developed. The articular head is strongly convex in medio-lateral direction.

\section{D3-4 (Fig. 3X, Y)}

Three roots. The mesial hyperloph becomes longer with wear; in less worn specimens it covers the lagiloph, and then "grows" to cover the entire postcone. The mesial hyperloph has a notch on the posterior edge. The mesial hypercone is much less developed than the distal one, both in size and width. Consequently, the hypoflexus appears as a very open "V". Both para- and mesoflexus are very deep, and their relative depth can vary: the paraflexus can be deeper than the mesoflexus or viceversa. The lagicone is small and thin; its connection with the very short lagiloph is bottlenecked. The postcone is rounded, with inclined axis and with a developed postlobule. 


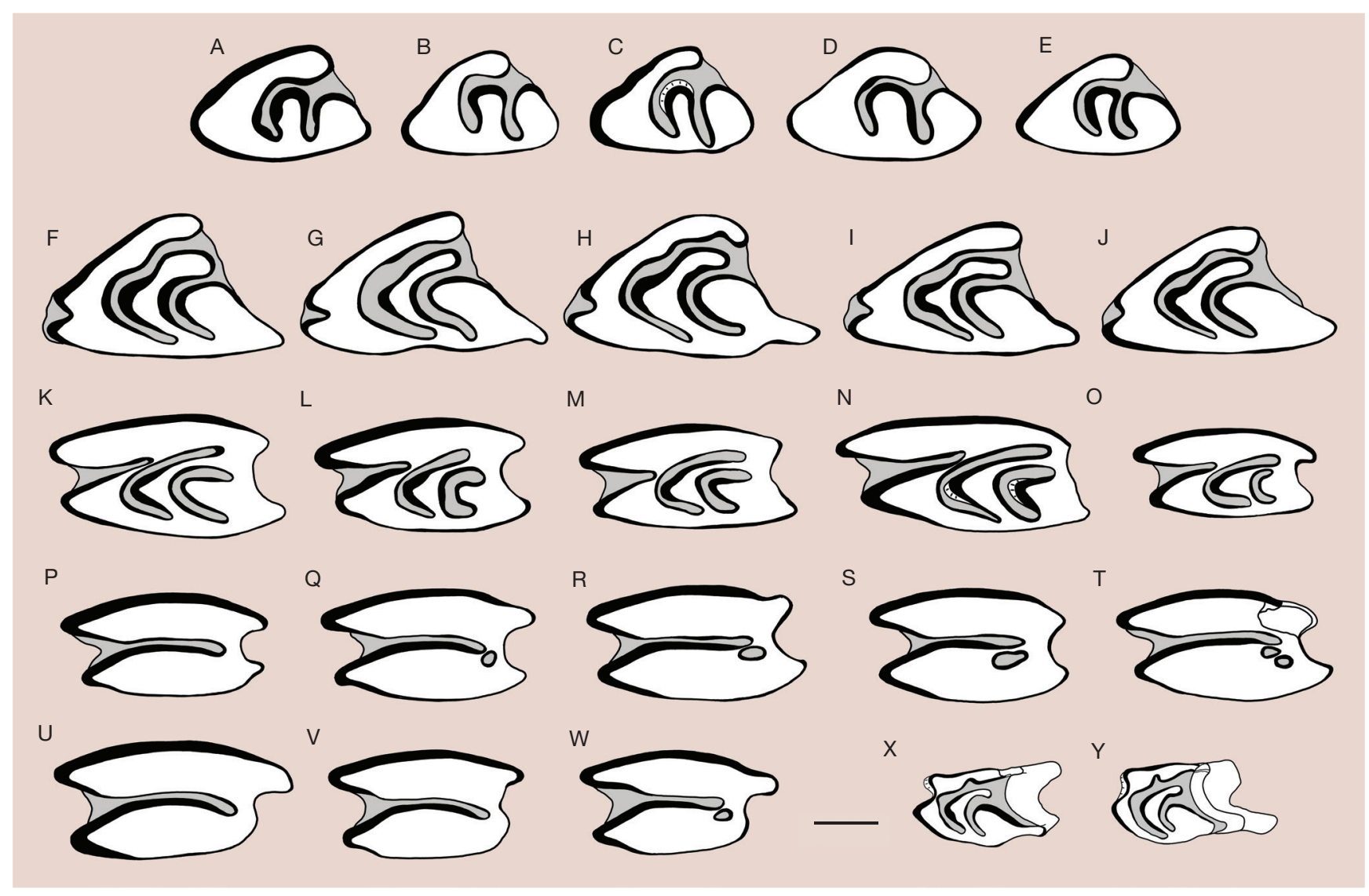

FIG. 3. - Occlusal morphology of upper teeth of Prolagus bilobus Heller, 1936 from the early Pliocene (MN15b) locality Gundersheim-Findling: A, left P2, SMF 1985/70; B, left P2, SMF 1985/71; C, right P2, reversed, SMF 1985/72; D, right P2, reversed, SMF 1985/73; E, right P2, reversed, SMF 1985/74; F, right P3, reversed, SMF 1985/86; G, left P3, SMF 1985/77; H, right P3, reversed, SMF 1985/78; I, right P3, reversed, SMF 1985/79; J, left P3, SMF 1985/82; K, left P4, SMF 1985/89; L, left P4, SMF 1985/91; M, left P4, SMF 1985/92; N, right P4, reversed, SMF 1985/99; O, right P4, reversed, SMF 1985/101; P, left M1, SMF 1985/109; Q, left M1, SMF 1985/110; R, left M1, SMF 1985/112; S, left M1, SMF 1985/111; T, right M1, reversed, SMF 1985/113; U, right M2, reversed, SMF 1985/127; V, right M2, reversed, SMF 1985/128; W, left M2, SMF 1985/129; X, left D3/4, SMF 1985/268; Y, left D3/4, SMF 1985/269. Scale bar: 1 mm.

\section{P2 (Fig. 3A-E)}

Quite flattened in shape. The mesial hyperloph is long, covering $67-78 \%(\mathrm{~N}=6)$ of the tooth width, often robust, and always without enamel hiatus. The lagicone is straight or very slightly inclined lingually, variable in thickness, and slightly longer than postcone in $83 \%(\mathrm{~N}=6)$, in one case with an undulation in its postero-lingual side. Paraand mesoflexus are deep and curved, with the latter longer than the former.

\section{P3 (Fig. 3F-J)}

The mesial hyperloph is of average thickness, slightly widened at the distal end, always without enamel hiatus $(\mathrm{N}=10)$. The mesial hypercone is lingually less protruding than the distal one. The hypoflexus is $\mathrm{V}$-shaped, from very shallow to shallow. The para- and mesoflexus are deep, curved, of equal depth or sometimes with the paraflexus as the deepest of the two. The lagicone-lagiloph complex is very thin in most cases, the lagicone-lagiloph connection is marked by a sharp change of the curvature. The lagiloph covers half or the entire postcone (in any case, never reaching the labial side of the tooth). The postcone is rounded or quadrangular, connected posterolabially to a postlobule of very variable size.

\section{P4 (Fig. 3K-O)}

The mesial hyperloph is more protruding lingually than the distal one, but it is much shorter (TH, i.e., its average length, is $40 \%$ of tooth $\mathrm{L}$ ). The hypoflexus reaches about $45 \%$ of tooth W (50\% of AA) and never merged with parafossette $(\mathrm{N}=21)$, it is $\mathrm{V}$-shaped in its lingual part, then becomes narrow U-shaped in $62 \%(\mathrm{~N}=21)$; the U-shaped part also has a different inclination with respect to the other part, i.e., pointing anteriorly. The parafossette is long to extremely long in its anterior part, slightly inclined towards the anterior side of the tooth in most cases, and its width remains constant all along, except for a few cases, in which the anterior end is slightly widened; sometimes the anterior end of the parafossettes covers and surpasses the mesofossette $(18 \% ; \mathrm{N}=22)$. The mesofossette is variable in size from large to very large, and in shape from V-shaped (predominant), to U-shaped and C-shaped.

\section{M1 (Fig. 3P-T)}

The mesial hypercone is more protruding than the distal one. The hypoflexus is very long (c. 79\% of W; c. 90\% of AA), curved posteriorly or straight. The fossettes are predominantly present; in $92 \%$ of cases $(\mathrm{N}=26)$ there is one fossette, in $4 \%$ 


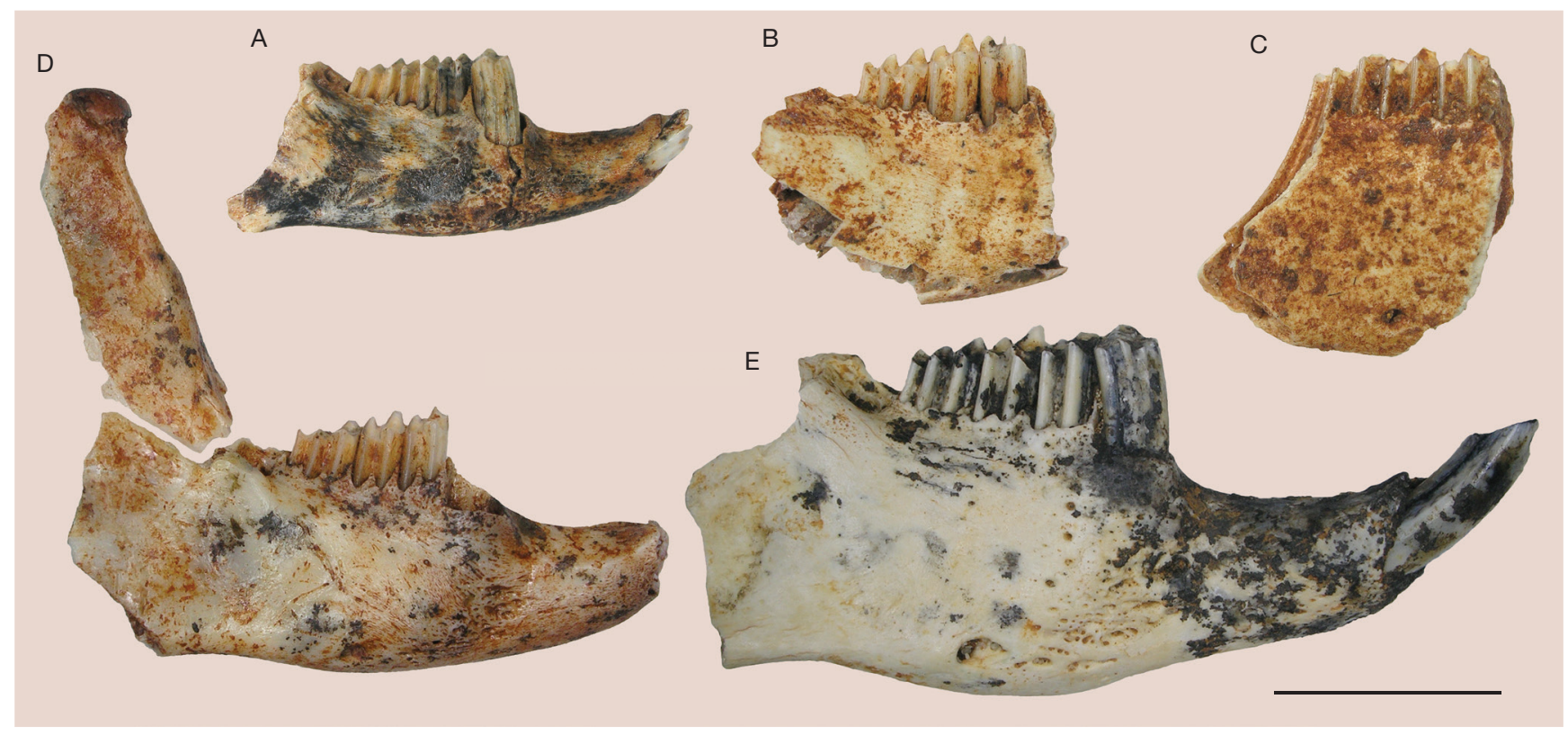

FIG. 4. - Mandibles of Prolagus bilobus Heller, 1936: A, juvenile right mandible with i1, p3-m2 (SMF 1985/165) from Gundersheim-Findling; B, fragment of right mandible with p4-m2 (SMF 1985/166) from Gundersheim-Findling; C, fragment of right mandible with p4-m2 (SMF 1994/895, paralectotype of $P$. bilobus) from Gundersheim (probably Gundersheim 1 sensu Tobien 1980); D, right mandible with p4-m2 (SMF 1996/156-157) from Gundersheim (unpublished material by F. Heller probably from Gundersheim 1 sensu Tobien 1980); E, right mandible with i1, p3-m2 (ZPAL M.10.) from Raciszyn 1. Scale bar: 10 mm.

of cases two fossettes, and in the remaining cases (4\%) fossettes are absent. The fossettes are positioned just under the distal end of the hypoflexus; they vary in shape from round to slightly oval ( $42 \% ; \mathrm{N}=24)$ to elongated $(58 \%)$.

\section{M2 (Fig. 3U-W)}

The precone is well-developed, the postlobule reduced. The mesial hypercone is slightly more protruding than the distal one. As with $\mathrm{M} 1$, the hypoflexus is very long (c. 78\% of W; c. $91 \%$ of AA) and curved posteriorly or straight. The fossettes are predominantly absent $(93 \% ; \mathrm{N}=15)$; when present, they are round and rather small.

\section{TAXONOMIC COMPARISON AND REMARKS}

Prolagus bilobus has recently been partly revised by Čermák \& Angelone (2013). The species is clearly differentiated by its very large p3 (Fig. 5) with lingually shifted, large, triangular, posteriorly, and buccally indented anteroconid; undulated sides of centroflexid; long crochet; metaconid of similar size as anteroconid; thick entoconid lacking enamel hiatus. The p3 of P. bilobus has a very homogeneous and stable morphology, as far as the anteroconid, crochet and entoconid are considered: all the adult individuals have a lingually displaced anteroconid with a unique "tilted" appearance, a voluminous crochet, and a thick, crenulated entoconid. These features seem unaffected by the intraspecific variability range. The $\mathrm{p} 3$ differs from that in: 1) P. pannonicus, P. sorbinii, P. latiuncinatus, $P$. caucasicus, $P$. michauxi, $P$. ibericus, and $P$. savagei in having a significantly larger size (Fig. 5); 2) P. pannonicus and P. caucasicus in having a larger and wider $\mathrm{p} 3$ anteroconid; 3) P. sorbinit, P. ibericus, $P$. depereti, $P$. savagei, and $P$. italicus in having a larger crochet; 4) $P$. caucasicus in having a quadrangular metaconid; and
5) P. michauxi and P. sorbinii in having a triangular indented anteroconid, vertically aligned with the entoconid.

The availability of additional materials allowed us to highlight some peculiarities of the species also in other tooth positions:

- d3 with its isolated labial cusp and predominance of separated talonid also in advanced stages of wear. This feature, which recalls P. crusafonti (see Angelone 2007: table 2, p. 413), can be considered as quite primitive. In fact, latest Miocene and Pliocene species (as far as we know, taking into account the scarce availability of fossil lagomorphs deciduous teeth and of detailed studies on the subject) are characterized by a connected talonid.

$-\mathrm{d} 4$ with a very deep paraflexid but not a centroflexid, as in late Miocene congeneric populations of western Europe.

- P2 with generally flattened appearance and very long mesial hyperloph. A flattened P2 is a common and stable feature of $P$. bilobus, but it is instead quite variable in other Pliocene species. The mesial hyperloph is remarkably longer compared to the Pliocene species $P$. pannonicus, $P$. latiuncinatus, and $P$. ibericus.

- P3 with centrocone not reaching the labial edge and P4 with long, upturned parafossette. Both characters are in common with the sorbinii group, providing a hint about the possible phylogenetic affinity of $P$. bilobus.

- P4 with mesial hyperloph remarkably thin.

The very thin dentine bridge between parafossette and hypoflexus in P4 of P. bilobus can be well observed in P. pannonicus and P. latiuncinatus; in Prolagus sp. from Beremend 39 these structures may even be confluent.

Tesakov \& Averianov (2002) attributed to P. bilobus scanty materials of isolated $\mathrm{p} 3 \mathrm{~s}$ from Tanatary (MD, MN15; 1 p3, formerly attributed to $P$. cf. oeningensis by Erbajeva \& 

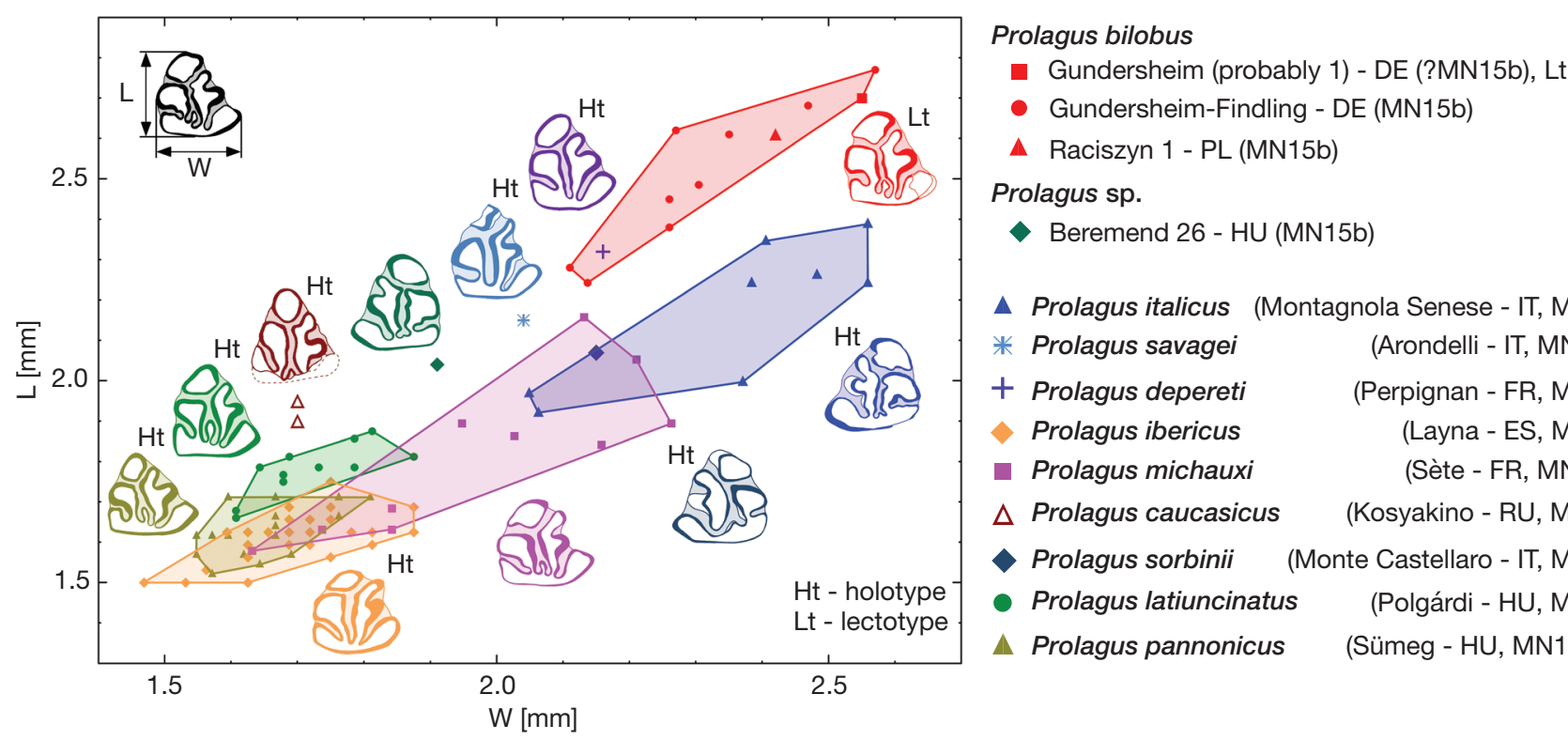

A Prolagus italicus (Montagnola Senese - IT, MN17)

* Prolagus savagei

(Arondelli - IT, MN16a)

+ Prolagus depereti

(Perpignan - FR, MN15)

$\checkmark$ Prolagus ibericus

(Layna - ES, MN15)

- Prolagus michauxi

(Sète - FR, MN15a)

$\Delta$ Prolagus caucasicus (Kosyakino-RU, MN14)

$\checkmark$ Prolagus sorbinii (Monte Castellaro - IT, MN13)

- Prolagus latiuncinatus (Polgárdi-HU, MN13)

Prolagus pannonicus (Sümeg- HU, MN10/11)

FIG. 5. - Comparison of p3 size of Prolagus bilobus Heller, 1936 and Prolagus sp. from Beremend 26 with materials from type localities (type materials or additional materials) of selected late Miocene-Pleistocene Prolagus species of Europe.

TABLE 2. - Mandibular measurements of Prolagus bilobus Heller, 1936: 1, Gundersheim-Findling, SMF 1985/165; 2, Gundersheim (probably Gundersheim 1 sensu Tobien 1980), SMF 1996/156, unpublished material of F. Heller; 3, Raciszyn 1, ZPAL M.10.

\begin{tabular}{lccr}
\hline Measurements & $\mathbf{1}$ & $\mathbf{2}$ & \multicolumn{1}{c}{$\mathbf{3}$} \\
\hline Lingual height of mandible at p3 & 4.89 & 7.13 & 9.09 \\
Lingual height of mandible at p4 & 6.50 & 9.01 & 12.98 \\
Lingual height of mandible at m2 & 6.23 & 8.56 & 12.25 \\
Length of diastema & 5.75 & - & 11.14 \\
Alveolar length of p3-m3 & 7.95 & 9.39 & 12.04 \\
Mandible width at p4 & 3.31 & 4.48 & 5.82 \\
Mandible width at m2 & 2.53 & 3.56 & 4.29 \\
\hline
\end{tabular}

Shushpanov (1988) and Erbajeva (1988)), Tatareshty (MD, MN15; 1 p3), Kotlovina (UA, probably MN15 or MN16 according to Nesin \& Nadachowski (2001); 1 p3, formerly attributed to $P$. cf. oeningensis by Agadjanian \& Erbajeva (1983)), and Kamenskoe (UA, age unclear, probably MN15; 1 p3, formerly attributed to Prolagus sp. by Topachevsky (1962)). These $\mathrm{p} 3$ are characterized by: 1 ) a small, not tilted anteroconid shifted towards the lingual side of the tooth; 2) a reduced, diamond-shaped metaconid with unfolded enamel, and 3) a reduced entoconid. Thus, they are quite different from P. bilobus. In the specimens from Tatareshty and Kotlovina, the crochet is absent or quite reduced, contrarily to adult specimes of $P$. bilobus. The measurements, available only for Tatareshty $(\mathrm{L} \times \mathrm{W}=1.95 \times 1.93$; Tesakov $\&$ Averianov 2002) and Tanatary $(\mathrm{L} \times \mathrm{W}=1.80 \times 1.70$; Erbajeva $\&$ Shushpanov 1988), indicate that the Moldavian specimens are sensibly smaller in size than P. bilobus. The overall morphology of the p3 of Ukrainian and Moldavian materials described above reminds the appearance of some populations of P. sorbinii (see Angelone 2007), a species distributed in Greece and Italy in the late Miocene and earliest Pliocene (Angelone \& Rook 2012). Thus, those remains are tentatively attributed here to $P$. aff. sorbinii.
For the sake of completeness, it is worth to mention that Tesakov \& Averianov (2002) tentatively referred to P. bilobus the population from Polgárdi (HU, MN13), a hypothesis refuted by Angelone \& Čermák (2015) who assigned the sample to the new species P. latiuncinatus.

To conclude, at present we include only the localities of Gunderhseim and Raciszyn 1 in the proven P. bilobus distribution, as the remains from Wölfersheim and Kisláng are at present not available (see above for details).

\section{Prolagus sp. \\ (Figs 6; 7)}

MATERIAL. - Beremend 26: 1 incomplete lower jaw sin with p3$\mathrm{m} 2$, IG Lag/Be26/01. Beremend 39: 2 incomplete upper jaws sin with P3-M2 and P4-M2, IG Lag/Be39/02, IG Lag/Be39/03; $1 \mathrm{~m} 1$ dex, IG Lag/Be39/04.

Measurements. - See Table 3.

STRATIGRAPHIC AND GEOGRAPHIC DISTRIBUTION. - Early Pliocene (late Ruscinian, MN15b); Beremend 26 and 39.

\section{DESCRIPTION}

\section{p3 (Fig. 6E [in part])}

Medium-size. The anteroconid is large, triangular in shape, not tilted (i.e., with posterior side perpendicular to the antero-posterior axis of the tooth), not perfectly central, but slightly displaced towards the lingual side of the tooth. There are no indentations, undulations, nor convexities on the labial and posterior side of the anteroconid. The metaconid is as large as the anteroconid, hatchet-shaped, with undulated labial and posterior sides. The metaisthmus is narrow, bottleneck-shaped. The entoconid is quite thick (length $>1 / 5 \mathrm{~L}$ ), without enamel hiatus. The protoisthmus 


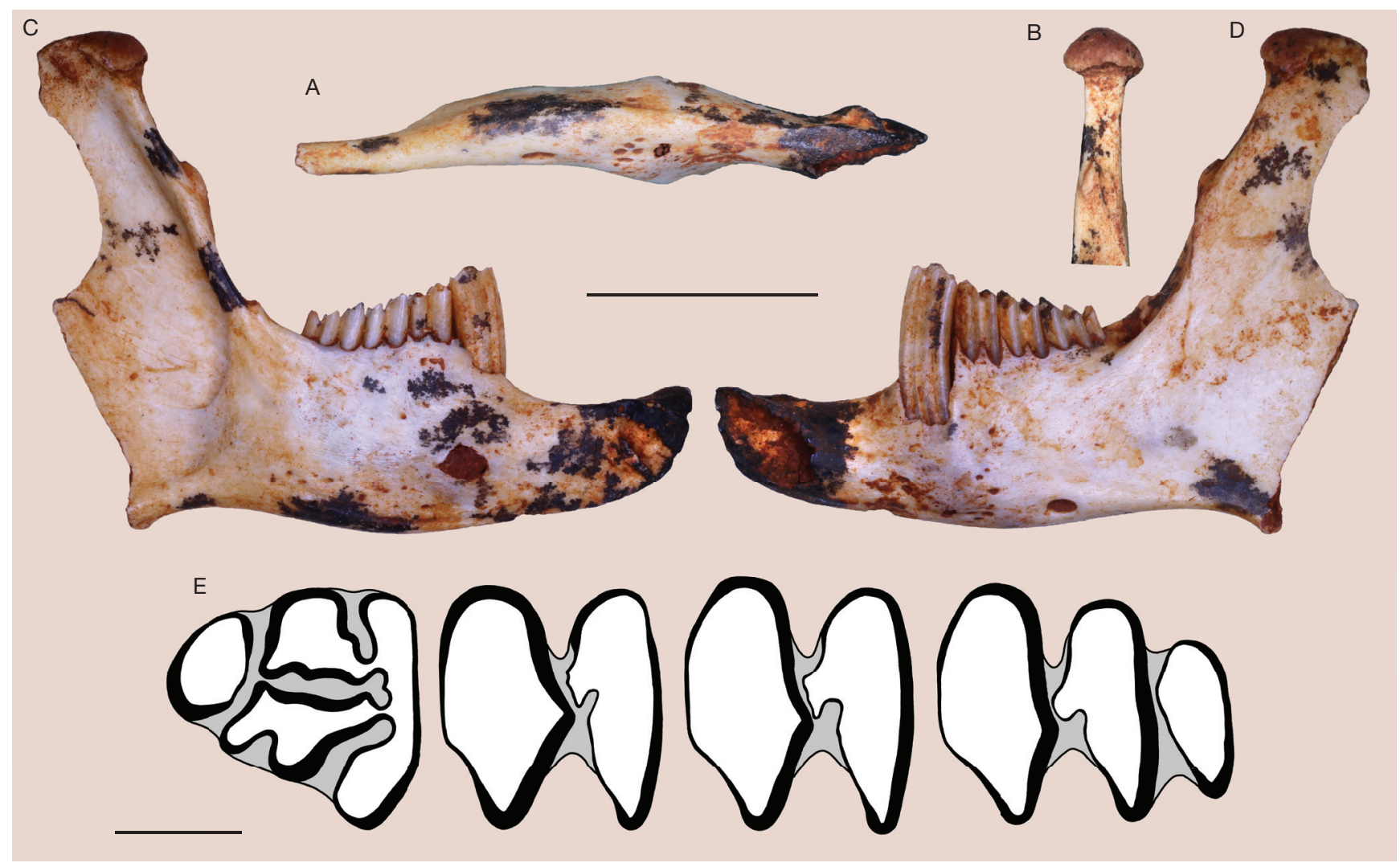

FIG. 6. - Mandible of Prolagus sp. from the early Pliocene (MN15b) locality Beremend 26: A-E, left mandible (IG Lag/Be26/01) with p3-m2 in (A) ventral, (C) lingual, and (D) buccal views; B, rostral view of the mandibular ramus; E, occlusal morphology of p3-m2. Scale bars: A-D, $10 \mathrm{~mm}$; E, $1 \mathrm{~mm}$.

is very narrow, bottleneck-shaped. The crochet is extremely feeble, in central position, symmetrical in shape. The centroflexid is straight, parallel to the antero-posterior axis of the tooth, with undulated sides, and enlarged at its distal end, in correspondence of the crochet. The hypoconid is small, triangular in shape, with flattened labial end. The protoconid is wide in its anterior part, narrowing towards the posterior part of the tooth in its distal part. The connection protoconid-protoconulid is marked by a spur. The protoconulid is relatively small, of average width.

\section{p4-m2 (Fig. 6E [in part])}

In $\mathrm{p} 4-\mathrm{m} 1$ trigonid and talonid have similar width and both show a thickening of the enamel on the posterior side. The trigonids are of rhomboid shape, longer than the talonids. In $\mathrm{p} 4$ the trigonid has an anterior step. The talonid shows an antero-labial flexid, more marked in $\mathrm{p} 4$, less marked in $\mathrm{m} 1$ and even less in $\mathrm{m} 2$. The three-lobed $\mathrm{m} 2$ have trigonid and talonid similar to other molariform teeth, plus a triangularshaped posterior lobe.

\section{Lower jaw (Fig. 6A-D)}

The outline is slender in both lateral and ventral views; the diastema is long, and its length is almost equal to the alveolar one. The posterior mental foramen is large, oval, located close the ventral edge of mandibular body in the area below $\mathrm{m} 1 /$ $\mathrm{m} 2$. Several accessory foramina are present below $\mathrm{p} 3-\mathrm{p} 4$. The lower incisor extends below the trigonid of $\mathrm{p} 4$. The ventral margin of the mandible is convex. The mylohyoid line is long, well-developed, and in ventral view appears located near the lingual edge of the mandibular body. The coronoid process is moderately developed. The articular head is strongly convex in medio-lateral direction.

\section{P3 (Fig. 7E [in part])}

The mesial hyperloph is thin, of constant width, without enamel hiatus, and covers part of the postcone. The mesial hypercone is less protruding than the distal one. The distal hyperloph, however, is very reduced in length. The $\mathrm{V}$-shaped hypoflexus is short. Para- and mesoflexus have the same depth, and reach posteriorly almost the edge of the tooth. The lagicone is of average size and rounded, the lagiloph has no indentations or steps, and the centrocone does not reach the labial end.

\section{P4 (Fig. 7D [in part], E [in part])}

The mesial hyperloph is slightly longer than the distal one; the length of mesial- and distal hyperloph is similar. The hypoflexus is $\mathrm{V}$-shaped in its lingual part, then takes a very narrow U-shape; in one individual the hypoflexus is connected to the parafossette, in the other, only a very thin enamel bridge separates the hypoflexus and the parafossette. The parafossette is very long, thin, and its anterior part may be upturned anteriorly; the mesofossette is C- or V-shaped, with the anterior tip slightly longer than the posterior one. 
TABLE 3. - Cranial and dental measurements of Prolagus sp. from the early Pliocene (MN15b) localities Beremend 26 and 39. See Material and methods for abbreviations.

\begin{tabular}{|c|c|c|c|c|c|c|c|}
\hline \multicolumn{2}{|l|}{ Mandible and maxillae } & \multicolumn{3}{|c|}{ Lower teeth } & \multicolumn{3}{|c|}{ Upper teeth } \\
\hline Total height of mandible & 21.37 & & & & P3 & $\mathrm{L}$ & 1.89 \\
\hline $\begin{array}{l}\text { Lingual height } \\
\text { of mandible at p3 }\end{array}$ & 6.46 & p3 & $\mathrm{L}$ & 2.04 & & W & 3.30 \\
\hline $\begin{array}{l}\text { Lingual height of } \\
\text { mandible at p4 }\end{array}$ & 8.18 & & W & 1.91 & & AA & 2.45 \\
\hline $\begin{array}{l}\text { Lingual height of } \\
\text { mandible at m2 }\end{array}$ & 7.92 & p4 & $L$ & 1.76 & P4 & $\mathrm{L}$ & $\begin{array}{r}1.50 \\
1.59\end{array}$ \\
\hline Length of diastema & 8.18 & & Ltrig & 1.05 & & $\mathrm{TH}$ & $\begin{array}{r}0.83 \\
0.84\end{array}$ \\
\hline Coronar length of $\mathrm{p} 4-\mathrm{m} 2$ & 6.08 & & Wtrig & 1.93 & & W & $\begin{array}{r}3.13 \\
3.18\end{array}$ \\
\hline Alveolar length of p3-m2 & 9.16 & & Wtal & 1.96 & & AA & $\begin{array}{r}2.68 \\
2.68\end{array}$ \\
\hline Mandible width at $\mathrm{m} 2$ & 3.20 & m1 & $\mathrm{L}$ & $\begin{array}{r}1.79 \\
1.91\end{array}$ & & $\mathrm{PH}$ & $\begin{array}{r}1.15 \\
1.33\end{array}$ \\
\hline Mandible width at p4 & 4.34 & & Ltrig & $\begin{array}{r}1.05 \\
1.15\end{array}$ & M1 & $\mathrm{L}$ & $\begin{array}{r}1.49 \\
1.58\end{array}$ \\
\hline \multirow[t]{4}{*}{ Width of articular head } & 3.95 & & Wtrig & $\begin{array}{r}2.01 \\
2.01\end{array}$ & & W & $\begin{array}{r}2.99 \\
3.08\end{array}$ \\
\hline & & & Wtal & $\begin{array}{r}1.98 \\
2.01\end{array}$ & & AA & $\begin{array}{r}2.65 \\
2.68\end{array}$ \\
\hline & & m2 & $\mathrm{L}$ & 2.33 & & $\mathrm{PH}$ & $\begin{array}{r}2.35 \\
2.36\end{array}$ \\
\hline & & & Wtrig & 1.92 & M2 & $\mathrm{L}$ & $\begin{array}{r}1.43 \\
1.50\end{array}$ \\
\hline Alveolar length of P2-M2 & $\begin{array}{r}9.54 \\
9.68\end{array}$ & & Wtal & 1.83 & & W & 2.85 \\
\hline Length of P2 alveolus & 1.95 & & Wtl & 1.31 & & AA & 2.54 \\
\hline Width of P2 alveolus & 2.86 & & & & & $\mathrm{PH}$ & $\begin{array}{r}2.16 \\
2.33\end{array}$ \\
\hline
\end{tabular}

\section{M1 (Fig. 7D [in part], E [in part])}

The mesial hyperloph is rather thin, longer than the distal one. The hypoflexus is rather long (c. $78 \%$ of W, c. $88 \%$ of AA; $N=2$ ), posteriorly curved; in 1 of 2 individuals, a round, small fossette is present posteriorly to the labial tip of the hypoflexus.

\section{M2 (Fig. 7D [in part], E [in part])}

The general features are the same as $\mathrm{M} 1$, with a relatively longer hypoflexus (c. $82 \%$ of $\mathrm{W}, c .92 \%$ of $\mathrm{AA} ; \mathrm{N}=1)$ and no fossette.

\section{Upper jaw (Fig. 7A-C)}

The hard palate is of average width. The posterior edge of the incisive foramen reaches the posterior edge of P2. The anterior edge of the choanae reaches the half of $\mathrm{P} 4$. The premolar foramen is large, oval, positioned medially to P4. Next to the maxillopalatine suture, there is a large palatine foramen, posteriorly accompanied by several smaller foramina. The masseteric spine is short and triangular in shape. The infraorbital foramen is oval, prolonged only slightly in dorsoventral direction. The infraorbital canal is short; in relation to the wall of P2 alveolus, placed rather dorsally.

\section{TAXONOMIC COMPARISON AND REMARKS}

The sole Prolagus specimen from Beremend 26, represented by an almost complete mandible, is extremely peculiar. Evident differences can be observed with respect to some late Miocene congeneric species (P. sorbinii / P. latiuncinatus), namely in its very large triangular anteroconid of p3. Prolagus sp. from Beremend differs from the Pliocene-Holocene species $P$. caucasicus, $P$. michauxi, P. ibericus, $P$. depereti, $P$. figaro, P. bilobus, P. savagei, P. italicus, and P. sardus, as its anteroconid is not displaced towards the lingual side. Moreover, the p3 of Prolagus sp. from Beremend 26 differs from that in: 1) $P$. pannonicus, P. latiuncinatus, $P$. caucasicus, and $P$. ibericus in having a larger size; (Fig. 5); 2) P. depereti, P. savagei, and P. bilobus in having a smaller size (Fig. 5);3) P. pannonicus and $P$. caucasicus in having a larger and wider $\mathrm{p} 3$ anteroconid; and 4) P. pannonicus, P. latiuncinatus, and P. bilobus in having a significantly less developed crochet.

Surprisingly, Prolagus sp. from Beremend 26 is morphologically and dimensionally incompatible with the coeval P. bilobus. The p3 of Prolagus bilobus has an extremely stable morphology (see section "Taxonomic comparison and remarks" about of $P$. bilobus). This characteristic makes impossible to "fit" in P. bilobus the lower jaw from Beremend 26, which p3 has a central, not tilted anteroconid, an extremely small crochet, and a medium-sized entoconid. Moreover, the lower jaw of Prolagus sp. from Beremend 26 has a different outline with respect to $P$. bilobus, especially in the ventral part (which is regularly convex and not angular), and in the size and position of the posterior foramen (smaller and positioned further posteriorly). Also the measurements of the $\mathrm{p} 3$ and of the lower jaw of Prolagus sp. from Beremend 26 are incompatible with an attribution to $P$. bilobus. In fact, though pertaining to an old individual, the measurements of $\mathrm{p} 3$ and lower jaw of Prolagus sp. from Beremend 26 fall below the distribution of adult P. bilobus (Fig. 5; Table 3). However, the upper teeth pertaining to a jaw excavated from Beremend 39, another karst filling of the Beremend karst complex, which apparently is coeval to Beremend 26, at least judging from the accompanying fauna (Pongrácz in litt.; Čermák \& Wagner 2013), do not show substantial differences in morphology and measures compared to P. bilobus (cf. Tables $1 ; 3$ ). This taxonomic incongruence between materials from coeval and neighbouring fissure fillings does not find an explanation for the moment and, though in our opinion Prolagus from Beremend 26 represents a distinct species, we provisionally keep all the available material from Beremend in open nomenclature as Prolagus sp.

It is really tempting to suppose that the p3 and only Prolagus specimen from Kisláng (Kretzoi 1954) may be related to Prolagus sp. from Beremend 26. Indeed, the geographical proximity of the fossil sites, and the age range of the mixed assemblage of Kisláng (MN15-MQ1; Mayhew 2012) are compatible with this hypothesis. However, the morpho-dimensional features of the p3 remain from Kisláng described in literature are too unclear to make any taxonomic speculation. Kretzoi (1954: 247) provided only indications about the presence of a crochet, and hypothesized a taxonomic proximity of the Kisláng specimen to Prolagus from Gundersheim. This is in contrast with our observation about the lower series from Beremend 26 (totally different from Gundersheim). We envisage the retrieval of the Prolagus materials from Kisláng, in order to solve this open issue. 


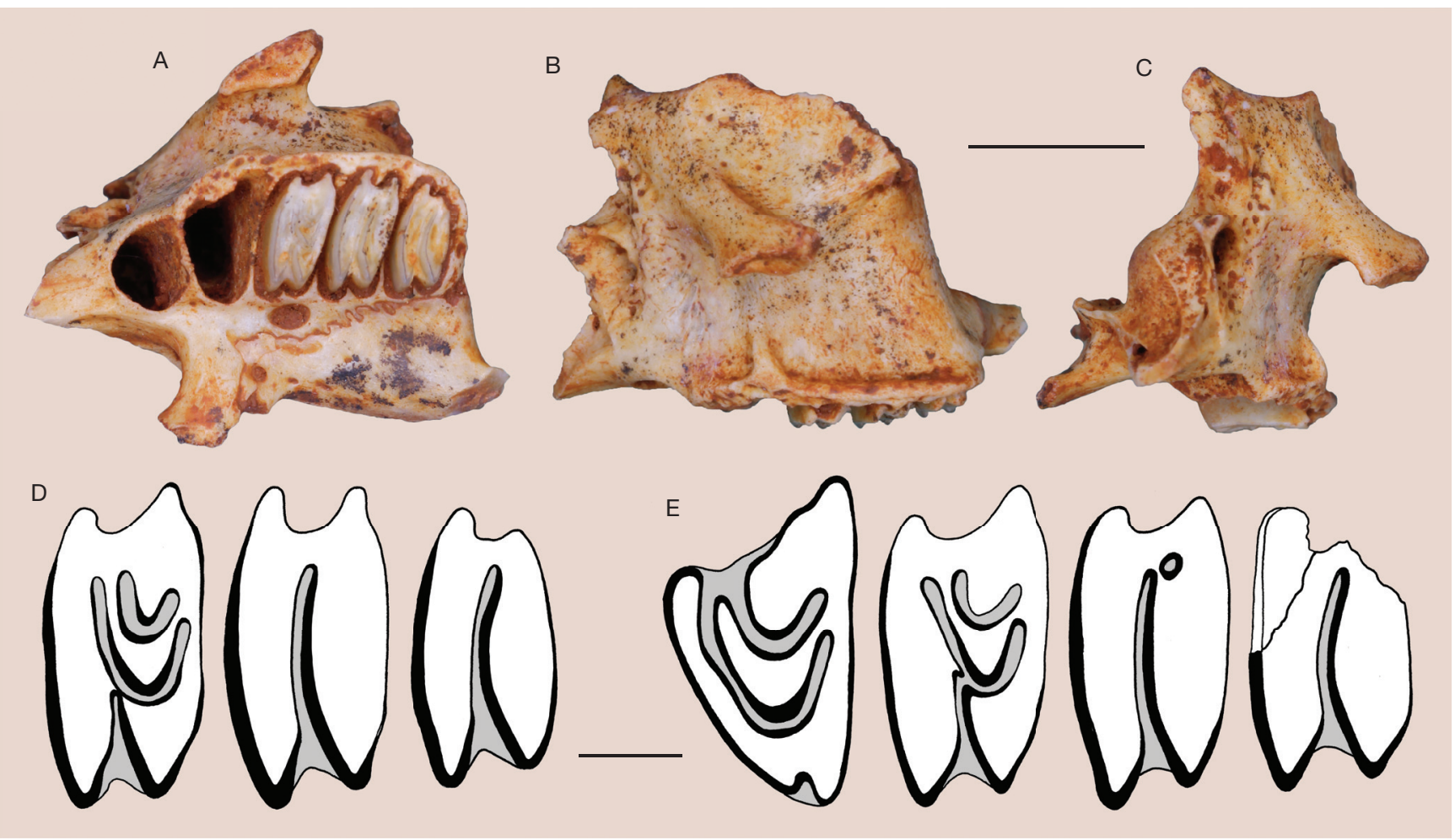

FIG. 7. - Maxillae of Prolagus sp. from the early Pliocene (MN15b) locality Beremend 39: A-D, left maxilla (IG Lag/Be39/03) with P4-M2 in (A) ventral, (B) buccal, and (C) rostral views; D, occlusal morphology of P4-M2; E, occlusal morphology of P3-M2 in left maxilla (IG Lag/Be39/02). Scale bars: A-C, 5 mm ; D, E, 1 mm.

\section{RESULTS AND DISCUSSION}

\section{NOTES ON THE ONTOGENY OF P. BILOBUS Mandibles}

The available jaws of $P$. bilobus cover various ontogenetic stages (Fig. 4) and show a noticeable size range (Table 2), typical of lagomorphs. Several allometric changes distinguish juvenile and adult individuals (see Fig. 4):

- the diastema is relatively shorter (compared to the alveolar row length) in the juvenile mandible (SMF1985/165) than in the unbroken aged specimen (ZPAL M.10). The values of $\mathrm{M}_{\mathrm{dL}}$ are $138 \%$ vs $108 \%$, respectively.

- the mandibular body is relatively lower (compared to alveolar row length) in the juvenile mandible (SMF1985/165) in contrast to that in the adult (SMF 1996/156) and aged (ZPAL M.10) ones. The values of $\mathrm{M}_{\mathrm{H}}$ are 70 vs 84 and $89 \%$, respectively (to exclude the influence of ventral curvature of the mandibular body, the height was calculated as the mean value of measurements at $\mathrm{p} 3$ and $\mathrm{m} 2$ ).

- a relative height increase of the mandibular body is associated with the curvature increase of its ventral margin; this phenomenon was also observed in the well-known and documented species Prolagus sardus (Tobien 1935: Fig. 2, p. 272).

The above described ontogenetic variations observed in the jaws of P. bilobus are quite standard for the genus. In Prolagus, though, also the position of the jaw posterior foramen slightly varies during the ontogeny, but in P. bilobus this feature remains unchanged in all the available specimens.

\section{Teeth}

In the genus Prolagus, the morphology of juvenile permanent teeth is quite different from the adults of the same species. This does not just depend by the fact that the cusps may be unworn: in fact, especially in $\mathrm{p} 3$, the relative size of the cusps, their connection, their position, and also their presence, are prone to noticeable variations during the ontogeny. Due to the progressive inclination of the wear surface (W) and the conical shape of the juvenile tooth shaft (L and W), also the size ranges of the teeth show a wide variation if juveniles are included in the measurements. It has even been observed, since the early studies about this taxon, that in some tooth positions the measurements cluster in two very distinct clouds, one for permanent juvenile teeth and one for adults (López Martínez 1974).

Also in the case of $P$. bilobus, it is possible to notice the remarkable ontogenetic changes in p3. Moreover, in this case, thanks to the stable occlusal surface morphology which characterizes this species (see "Taxonomic comparison and remarks" of $P$. bilobus) and thanks to a sufficient number of specimens for both ontogenetic categories ( 6 conical p 3 in the initial stage of abrasion = permanent juvenile teeth; and 14 p3 with prismatic shafts = permanent adult teeth), we were able to observe in the occlusal and "radical" parts of the teeth the following pattern (young to old):

- the enlargement, deformation, and tilting of the anteroconid;

- the deformation of the metaconid; 
- the noticeable thickening of the protoconulid;

- the thickening of the entoconid;

- the appearance or the enlargement of the crochet.

The ontogenetic changes observed in P. bilobus can not represent a pattern perfectly applicable to other congeneric species. However, it would be worth to verify if the patterns of ontogenetic trajectories are similar in phylogenetically close species.

It is very interesting to notice the extreme ontogenetic dimensional change between the deciduous and the permanent teeth of P. bilobus (Fig. 8). Indeed, López Martínez (1974) noticed that the relative proportion of the length of $\mathrm{d} 3$ and $\mathrm{p} 3$ varies through time in the species of the genus Prolagus, but this observation had no further development in literature. Thirteen selected fossil localities ranging in age from the early Miocene (MN2b) to the Late Pleistocene with sufficient materials of d3/p3 were selected to verify and further investigate López Martínez's (1974) remark. Materials from different ages, but also from different geographical areas were selected, in order to exclude possible biases. It appears (Fig. 8) that in early Miocene to early middle Miocene species, Ld3 is larger than Lp3 (mean value of the $\mathrm{K}_{\mathrm{d} / \mathrm{p}}: 110-123 \%$ ), as occurs in Prolagus ancestor Piezodus Viret, 1929 (see López Martínez 1974). Since the late middle Miocene, the size ratio is reversed, i.e., Lp3 is larger than Ld3. Moreover, it is remarkable that after the reversal of size proportions, the size of $\mathrm{d} 3$ not only remains small, but also relatively stable. The size of $\mathrm{p} 3$, on the contrary, though showing a general increase, is variable, consequently the size differences between $\mathrm{d} 3$ and $\mathrm{p} 3$ are also quite variable. The mean value of $\mathrm{K}_{\mathrm{d} / \mathrm{p}}$ ranges from $98 \%$ in P. tobieni from the MN7/8 of Escobosa to $55 \%$ in P. bilobus from the MN15b of Gundersheim-Findling, which is the species with the largest $\mathrm{d} 3 / \mathrm{p} 3$ size difference among the studied taxa (Fig. 8). The percentage of size difference between $\mathrm{d} 3$ and $\mathrm{p} 3$ in the analyzed taxa does not evidence a gradual trend depending on the geologic age, as hypothesized by López Martínez (1974: 142). Of particular interest in this sense, is to observe that two distinct species, $P$. tobieni and $P$. oeningensis, recorded from the same locality (Escobosa, Spain), show a quite different $\mathrm{K}_{\mathrm{d} / \mathrm{p}}$. It can not be excluded that, within a mosaic evolutionary pattern, which is commonly observed in Prolagus, the size differences between d3 and p3 may carry a signal of phylogenetic closeness of species within distinct clades. At any rate, this parameter may be useful for species discrimination (cf. Álvarez-Sierra et al. 1990: 16), and it may have a biochronological significance, being a real turning point in the evolution of Prolagus similarly to:

- the appearance of the centroflexid. The presence of a long centroflexid became a stable feature of the genus after the $P$. vasconiensis/oeningensis transition, near the early/middle Miocene boundary. The only exception is a conservative clade endemic to Spain, whose last representant was P. tobieni (still possessing a very incipient centroflexid), a species which survived until the early late Miocene (according to Hordijk \& van der Meulen 2010).

- the appearance of the mesial hyperloph in P2 coupled with the sudden increase of Lp3. These features make a panEuropean, "simultaneous" appearance between MN12 and
MN13 (Angelone 2007; Angelone \& Čermák 2015 with references). The only known exception is the MN15 P. ibericus, an extremely peculiar species whose phylogenetic history is quite mysterious and characterized by several "incongruent" features compared to coeval ones (first of all the very small size), known only from the type locality Layna (NE Spain; López Martínez 1989). It must be remarked, though, that in spite of all its peculiarities, the $\mathrm{K}_{\mathrm{d} / \mathrm{p}}$ of $P$. ibericus is congruent with that of coeval species.

\section{EVOLUTIONARY TRENDS IN PROLAGUS P3: CENTRAL VS WESTERN EUROPEAN PliOCENE SPECIES Size}

The dental size (p3) of European prolagids shows a general increase trough time, with a few countertrending episodes (e.g. P. oeningensis $\rightarrow$ P. crusafonti; López Martínez 1989) and an interesting sudden enlargement in correspondence of the MN13 (Angelone 2007). Until Miocene, though, the size range of the $\mathrm{p} 3$ of coeval Prolagus species is comparable (with punctual exception as P. major in the MN6 of Spain; López Martínez 1989). During the Pliocene, instead, Prolagus shows a wide range of size (Fig. 5): from quite small (e.g. P. ibericus; Layna, MN15) to very large (e.g. P. bilobus; Gundersheim-Findling, Raciszyn 1, both MN15b, which is the largest continental species of the genus).

\section{Enamel folding and entoconid thickness}

Morphological patterns corresponding to temporal trends were individuated in the p 3 of western European Plio-Pleistocene species, namely the simplification of the enamel folding pattern (particularly the loss of the crochet and the smoothing of anteroconid and metaconid folds) and the reduction of the entoconid (Angelone 2008a).

The detailed study of $P$. bilobus and Prolagus sp. from Beremend 26 allowed to verify if those trends are shared also by Pliocene Prolagus of central Europe. The answer is negative. Prolagus bilobus and Prolagus sp. from Beremend 26 do not follow the above listed morphological trends, possessing a folded enamel and a thicker entoconid (this feature is particularly evident in the former species). In this sense, they are similar to $P$. italicus, whose peculiarities were explained by Angelone (2008a) as a consequence of its status of peninsular Italian endemic species. Hypothesizing that the morphological analogies between P. italicus, P. bilobus, and Prolagus sp. from Beremend 26 are common to continental isolated species, however, is quite simplistic in our view. In fact, the conditions of isolation (geographical extent, duration, dynamics, and climate) of these species are too different to justify a shared common morphological trend in the teeth occlusal surface. Possibly, some of the similarities shared by P. bilobus, P. italicus, and Prolagus sp. from Beremend 26 and, consequently, their divergence from Pliocene western European species, may derive from a common origin from an eastern European stock. In fact, $P$. italicus, though known only from the MN17 of central Italy, stemmed from the eastern European species $P$. sorbinii just after its dispersal into Italy, an event occurred in the Messinian (see cladistics 


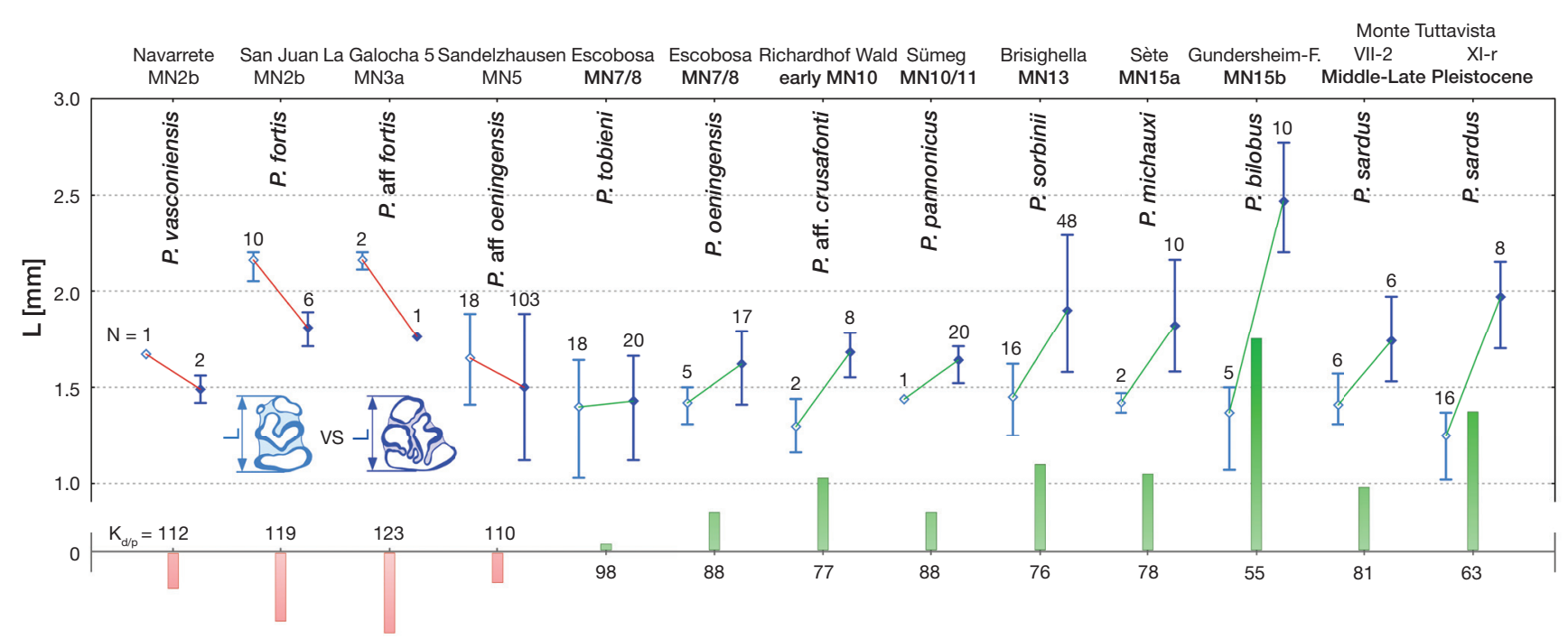

FIG. 8. - Comparison of d3 and p3 lengths (indicated respectively by lighter blue bars and points and darker blue bars and points) in selected early Miocene to Late Pleistocene Prolagus species of Europe. Red/green bars show negative/positive values of $D_{p-d}$. Values above or below bars are relative to $K_{d / p}$ values. See Material and methods for abbreviations.

analysis in Angelone et al. 2015; palaeobiogeographical and taxonomic details in Angelone et al. 2019, 2020). There is no available analysis at present to support the origin of P. bilobus and Prolagus sp. from Beremend 26 from eastern European species, though it can be a palaeobiogeographically sensible hypothesis. A definitive answer can be obtained only after the revision of Pliocene Prolagus species from eastern Europe and Anatolia.

\section{Entoconid enamel hiatus}

As stated above, an eastern origin for P. bilobus and Prolagus sp. from Beremend 26 can only be hypothesized, but an encouraging hint in that sense (waiting for a phylogenetic analysis) can be the presence of an enamel hiatus in the entoconid of p3. Angelone (2008a) hypothesized a delayed acquisition of the enamel hiatus in the Italian P. sorbinii-italicus stock (in $P$. sorbinii the hiatus is absent, whereas in P. italicus only a partial hiatus may be present) in contrast to "the European lineage" i.e., western European species, which indeed represent a separate clade; see Angelone et al. 2015), and in which the presence of the enamel hiatus can be observed since the latest Miocene (MN13, Messinian). However, other studies (Čermák \& Angelone 2013; Angelone \& Čermák 2015; this study) documented the absence of entoconid enamel hiatus also in the central European taxa P. latiuncinatus (Polgárdi 2, MN13), P. bilobus (Gundersheim-Findling, Raciszyn 1, both dated to MN15b), and Prolagus sp. (Beremend 26, MN15b). This evidence reinforces the hypothesis of a south-eastern European phylogenetic affinity of P. bilobus and Prolagus sp. from Beremend 26.

\section{EXPLAINING THE CENTRAL EUROPEAN}

Distribution of Prolagus DURING THE Pliocene

The Pliocene remains of Prolagus recorded at the northern border of its geographical range were generally considered to be isolated endemic populations, relicts left behind after the reduction of the formerly homogenous Miocene distribution of the genus, a phenomenon that became quite evident since the Pliocene (López Martínez 2001). Nevertheless, in our view, there may be an alternative explanation for the Prolagus occurrences in the Pliocene of central Europe.

\section{Palaeoclimatical background}

The genus Prolagus appeared during the early Miocene (MN2b), i.e., towards the end of a period of stable climatic conditions (late Oligocene-early Miocene, MP28-MN3, $c$. 27-17 Ma; Maridet et al. 2007). In this period, Europe was characterized by a homogeneous mammal fauna with high interregional taxonomic affinities (sensu Raup \& Crick 1979). The situation became increasingly heterogeneous since the end of the early Miocene (MN4, c. 17-16.5 Ma). At a larger scale, we assist at a general global cooling trend started about $14 \mathrm{Ma}$ (Zachos et al. 2001). In Europe, an abrupt end of the warm period has been recorded at 14-13.5 Ma (Böhme 2003), and since the middle Miocene, several cooling and warming pulses, as well as several fluctuations in the precipitation rate occurred (Böhme et al. 2008 with references). In particular, the transition to a drier climate and a concomitant cooling episode (c. 9.7-9.5 Ma) determined the biotic crisis known as the Vallesian crisis (but see Casanovas-Vilar et al. 2014). The climatic trend induced a strong latitudinal differentiation in the European climates. In the precipitation regime, a quite evident latitudinal differentiation between northern and southern Europe occurred at $c .8 \mathrm{Ma}$ (Böhme et al. 2008). The study of European faunal assemblages evidences the strong isolation of some regions during the late Miocene. Since the latest Miocene and until the first part of the early Pliocene (MN13-MN14, c. 6.5-5 Ma), a renewed faunal homogeneity shortly occurred in the peri-Mediterranean area of Europe (Maridet et al. 2007). 
The early Pliocene is considered to be a period of globally warm climate (De Schepper et al. 2014 with references), though interrupted by short-lived glacial events (c. 4.9/4.8 Ma, and c. $4 \mathrm{Ma})$. Since the early/late Pliocene transition $(3.6 \mathrm{Ma})$, the relatively stable humid conditions which characterized Europe during the early Pliocene came to an end. The increase in coolness and dryness culminated with a global glaciation at c. $3.3 \mathrm{Ma}$ (MIS M2; see De Schepper et al. 2009 and Tan et al. 2017, both with references). The glaciation, though intense (comparable to early Quaternary glaciations) was short-lived (50 ky) and followed by the mid-Piacenzian Warm Period (c.3.3-3.0 Ma) (Tan et al. 2017). Though characterized by a climate deterioration if compared to the early Pliocene, the interval 3.6- c. 3.0 Ma was "the last sustained interval in Earth's history when global climate was warmer than today" (De Schepper et al. 2009). Between c. 3.0-2.7 Ma is recorded the onset of the Northern Hemisphere glaciation. Such event, contrarily to the quite ephemeral late Eocene to early Pliocene glaciations (Lunt et al. 2008), is the forerunner of the glacial-interglacial cycles of the Quaternary (Ganopolski \& Calov 2011).

The Pliocene environmental changes impacted on mammalian evolution and dynamics, driving extensive rearrangements of community and faunal structures, including large scale migrations and rearrangements of the selection pressure upon the phenotypic design of particular taxa. A short period near the early/late Pliocene boundary $c$. MN15-16) represents one of the most dramatic global turning points of the late Cenozoic faunal history. Nearly a half of the Neogene mammalian taxa disappeared at that time, and almost all the elements constituting the modern Quaternary communities appeared in that stage as well (Bernor et al. 1996; Rössner \& Heissig 1999; Reumer \& Wessels 2003). The aridisation and spread of open ground habitats grew particularly pronounced at the MN16/17 boundary (c. $2.5 \mathrm{Ma}$ ), as attested by the loess deposits recognized throughout the northern hemisphere (Rabeder 1981; Rabeder \& Verginis 1987; Tedford et al. 1991; Shi 1994; Xue et al. 2006).

\section{A focus on Pliocene palaeoecology of central Europe with emphasis on the distribution of lagomorphs}

In the Pliocene of Europe, the climatic changes resulted in a decoupling of the climatic regime of northern and southern Europe. Relatively warmer and arid conditions characterized the Mediterranean area, in contrast to the onset of cooler and humid conditions in the northern parts of central Europe (Popov 2004). The plant record indicates that, in the early Pliocene (before $c .4 \mathrm{Ma}$ ), mixed mesophytic forests and broad-leaved deciduous forest prevailed in the studied area (Kovar-Eder et al. 2008). Indeed, Pliocene faunas of central Europe (documented particularly from the localities Gundersheim-Findling, Węże 1, and Csarnóta 2) contain a large proportion of mesophilous lypotyphlan and rodent species (>70\%; ecogeographical group 1 sensu Popov 2004). This is indicative for an even and humid climate. The other $30 \%$ of the assemblages is represented by species with relatively wide tolerances, adapted to a wide range of biotopes under more continental and arid climate (ecogeographical group 2 sensu Popov 2004), inhabiting edge habitats such as dry open forests, bushes, dry meadows, etc. In the Mediterranean area, the genera of group 1 are absent or are very poorly represented, whereas those of group 2 are predominant, together with genera characteristic of dry open habitats (mostly dry savanna dwellers ecogeographical group 3 sensu Popov 2004). See Kretzoi (1956, 1962), Sulimski (1959, 1962, 1964), Kowalski (1960), Repenning (1967), Michaux (1971), Jánossy (1972, 1986), Van de Weerd \& Daams (1978), Van de Weerd (1979), Skoczen (1980), Van de Weerd et al. (1982), Reumer (1984, 1989), Van der Meulen \& Van Kolfschoten (1986), Fejfar \& Storch (1990), Terzea (1997), Şen (1998), Şen et al. (1998), Ünay \& de Bruijn (1998), Popov $(2001,2003,2004)$, Fejfar et al. (2006) for details.

The lagomorph diversity in the late Ruscinian localities (MN15b, i.e., coeval with the Prolagus samples under study) of central and south-eastern Europe is quite high (see Kretzoi 1962; Sych 1965; Daxner \& Fejfar 1967; Fladerer \& Reiner 1996; Terzea 1997; Dahlmann 2001; Popov 2004; Čermák 2007, 2009; Čermák \& Angelone 2013; Čermák \& Wagner 2013). Five species of lagomorphs pertaining to five distinct genera (Ochotonoma Şen, 1998, Prolagus, Hypolagus Dice, 1917, Pliopentalagus Gureev \& Konkova in Gureev, 1964, Trischizolagus Radulesco \& Samson, 1967) are recorded. The palaeobiogeographical trajectory and the biochronological importance as MN15b markers of some of them is well documented (Angelone 2008b; Čermák \& Wagner 2013). The most common lagomorph was $H$. petenyii, which occurred in almost all central and south-eastern MN15b European localities. This species is usually regarded as a forest dweller (Fladerer \& Reiner 1996). Trischizolagus dumitrescuae Radulesco \& Samson, 1967 and O. csarnotana generally occur together in the Pliocene of Europe. Their presence indicates a rather dry and hot climate, and the presence of vast areas of savanna-steppes (Popov 2004). Most of the available remains of $T$. dumitrescuae are known from the northern part of the peri-Paratethyan area, in fossil sites of early Ruscinian age (MN14). Western occurrences of T. dumitrescuae are rather rare and exclusively limited to the late Ruscinian (MN15b). Ochotonoma csarnotana from Beremend 26 (Čermák \& Wagner 2013) so far represents the westernmost proven record of the species. European occurrences of O. csarnotana are limited to south-eastern regions and are closely related to the distribution of Ochotonoma in Anatolia (see Čermák 2007 for details). The distribution range of $T$. dumitrescuae and $O$. csarnotana in central Europe does not exceed latitude N46 (occurences in Beremend 26/39 and Csarnóta 2). On the contrary, the distribution range of Pliopentalagus dietrichi clearly exceeds this latitude and reaches the Rhine Graben (western Germany), together with P. bilobus (co-occurrences in Gundersheim-Findling and probably in Wölfersheim). Pliopentalagus dietrichi may be considered, by analogy with its extant relative Pentalagus furnessi (Stone, 1900), a forest dweller inhabiting dense subtropical forests characterized by a low cursorial ability. In this framework, it is difficult to guess the environmental requirements of $P$. bilobus and Prolagus sp. 
from Beremend. Possibly the latter was more related to a dry and open habitat, given the ecological requirements of the other lagomorphs found in the same assemblage, but the former may have pertained to either ecogeographical group 1 or 2 (sensu Popov 2004).

It is evident that in MN15b a conspicuous number of the lagomorph genera reached central Europe, most of them from eastern or south-eastern regions. Such appearance of lagomorph taxa with very different ecological requirements, all together in a short time span, suggests that the onset of favourable climatic conditions was not the only and/or primary driving factor of their coeval dispersal.

\section{The post-Miocene fate of Prolagus:}

climate change, palaeogeography, competitive pressure

It is clear from the climatic and ecological frameworks above illustrated that, except for the earliest stages (MN2b-MN3), Prolagus developed and passed unscathed through periods of profound climatic/environmental changes for at least 14 of the c. 20 my of its evolutionary history. Actually, Prolagus species had a wide range of environmental adaptations. Several species lived in subtropical forest or wetland lacustrine habitats, nevertheless other species, i.e., P. ibericus from Layna (MN15) or Prolagus spp. from the Gargano palaeoarchipelago, inhabited arid environments (López Martínez 2001). It is also possible that several of those species did not have strict ecological requirements. Anyway, Prolagus was quite adaptable to different and variable climatic conditions. Thus, it is reasonable to suggest that climate change sensu stricto was not the primary reason for the limited distribution of Prolagus in the Pliocene of central Europe.

A different perspective on the distribution of the genus Prolagus in Europe comes from the palaeogeographical approach. Until the middle Miocene, the geographic distribution of Prolagus was arranged in a roughly latitudinal band (as far as the distribution of emerged lands permitted; cf. López Martínez 2001 for Prolagus distribution data, and Popov et al. 2004 for updated palaeogeographic setting). During the late Miocene, the area in which Prolagus was distributed was deformed by the Alpine arc in its central part (the radial axis of the arc, coinciding with the Rhine graben, was "pushed" northwards; see Sue et al. 2007). The bending movement may have had an effect on isolation (the question is how much) between western and eastern Prolagus populations, with the Alpine arc and the Bohemian Massif acting as physiographic barriers. Indeed, significantly increasing differences between western European Prolagus species and central-eastern European ones start to be noticed at least since MN10 (Angelone \& Veitschegger 2015).

The decline in Prolagus abundance in northern central Europe appears evident already since the late Miocene (López Martínez 2001). Although the mammalian fossil record around the Miocene/Pliocene boundary (late MN13 to MN14) is extremely rare north of the Alps, Prolagus had probably disappeared there since the latest Miocene. Further south, in the Pannonian Basin, the genus was still present in the MN13 (Angelone \& Čermák 2015). For sure, Prolagus is absent in the Pliocene of central Europe except for MN15b: $c .30$ vertebrate-bearing fossiliferous localities are known between MN14-16 (Wagner et al. 2009) and the occurrences of Prolagus are exclusively limited to the 6 localities (out of a total of the 11 available for MN15b). Such chronologically limited occurrences are indicative of a dispersal, rather than of a progressive Pliocene shrinking of the Miocene distribution area that left isolated endemic populations. This dispersal most probably occurred from south-eastern regions of Europe (e.g. the NW peri-Black Sea area), as the main morphological characters of central European Pliocene Prolagus here analyzed is quite different from those of western European ones. Moreover, a dispersal wave from eastern regions fits quite well in the framework of the above discussed extensive faunal rearrangements occurred during the early Pliocene.

The subsequent, relatively sudden, disappearance of Prolagus from central Europe after MN15b can be explained by the increase of the competitive pressure related to the continuous global climatic degradation during the late Pliocene. In this sense, Prolagus met the same fate of Pliopentalagus dietrich $i$ in Europe (see Čermák \& Wagner 2013). In fact, the Pliocene climatic deterioration caused an increase of the aridisation and the spreading of open ground habitats in central Europe. This opened the way for Ochotona Link, 1795 and Lepus Linnaeus, 1758, very well adapted for those landscape settings, and the Prolagus "story" in central Europe was over and was never repeated again.

\section{CONCLUSIONS}

This paper fills a gap in the study of Pliocene prolagids, until now mainly centered on western European species, performing a detailed analysis of all available published and unpublished Pliocene materials of Prolagus from central Europe.

Most of the record of central European Pliocene Prolagus pertains to Prolagus bilobus. This species is reported here from the MN15b localities of Gundersheim and Raciszyn 1. Some materials of $P$. bilobus had already been revised and its diagnosis emended (Čermák \& Angelone 2013), however the availability of relatively rich materials allowed to define here some additional peculiarities in tooth positions other than $\mathrm{p} 3$. The extremely low intraspecific variability of the specimens of $P$. bilobus is striking. This characteristic allowed to easily describe the ontogenetic trajectory of the p3 of P. bilobus. From juvenile to adult, the p3 undergoes the enlargement, deformation, and tilting of the anteroconid, the deformation of the metaconid, a noticeable thickening of the protoconulid, the thickening of the entoconid, and the enlargement of the crochet. In the mandibles of adult specimens, compared to the juveniles, it is possible to observe an enlargement of the diastema in relation to the alveolar row length, the heightening of the mandibular body, and an increase of the curvature in the outline of the ventral margin.

The study of the ontogenetic development of P. bilobus was extended to the deciduous teeth (d3), and the dimensional results were compared with Prolagus species from several fossil 
localities ranging in age from the early Miocene (MN2b) to the Middle-Late Pleistocene. In early Miocene-early middle Miocene taxa, the $\mathrm{d} 3$ is larger than p3, as occurs in Piezodus (López Martínez 1974). However, since late middle Miocene, the size relationship appears reversed, and the values of $\mathrm{d} 3$ remain quite stable. The reversal is not gradual: the $\mathrm{d} 3 / \mathrm{p} 3$ relative length proportion is one of the characters that, in the genus Prolagus, change their state at a certain geological moment and in a trans-specific way, and, in this sense, it may have a biochronological value. At any rate, the size difference between $\mathrm{d} 3 / \mathrm{p} 3$ in P. bilobus is clearly the largest among the studied taxa.

New materials from Beremend 26 and 39 (MN15b) revealed the presence of a possible new species of Prolagus. A lower jaw of an adult individual from Beremend 26 appears clearly distinct from other Pliocene-Holocene congeneric species. In particular, the differences with the coeval P. bilobus are striking. Teeth and mandible dimensions fall below the lower range of P. bilobus, and also the morphology of $\mathrm{p} 3$ is incompatible with P. bilobus. Nevertheless, an upper jaw excavated from the neighbouring fissure filling Beremend 39 does not show substantial differences in morphology and measures with P. bilobus. The two fillings seem coeval, basing on the biochronological indications given by the faunal content. These contradictory taxonomic evidences can be solved only by the retrieval of additional material, and the prolagids from Beremend 26 and 39 are provisionally left in open nomenclature as Prolagus sp.

Ukrainian and Moldavian MN15-?16 materials attributed by Tesakov \& Averianov (2002) to P. bilobus do not match the diagnosis of the species and, in our opinion, should be provisionally referred to $P$. aff. sorbinii. The material from Kisláng (mentioned by Kretzoi 1954) could have shed light on the subject. Unfortunately, the material is currently unavailable. The same fate was suffered by the Prolagus remains from Wölfersheim (faunal list in Tobien 1977; eventually reported also by Dahlmann 2001).

Contrarily to the "traditional" view (López Martínez 2001), we hypothesize that central European Prolagus are not relict species "left behind" after a progressive reduction of the geographic distribution of the genus due to climate deterioration s.s. occurred during the Pliocene. Prolagus disappeared from northern central Europe since the latest Miocene to reappear briefly in the late early Pliocene (MN15b). This evidence rather indicates a sudden dispersal, most probably from south-eastern regions of Europe, as the morphology of P. bilobus and Prolagus sp. studied herein exclude close phylogenetic affinities with western European species. Prolagus is not the only lagomorph to appear in central Europe in MN15b: others are e.g. Pliopentalagus and Ochotonoma, two taxa of clear eastern origin.

The MN15b central and south-eastern Europe lagomorph palaeobiogeographic dynamics represent only a tile of the extensive faunal rearrangements that characterize the entire Europe during the Pliocene. The post-Miocene fate of Prolagus in central Europe was determined by a combination of palaeogeographic and climatic changes which caused extensive rearrangements of community and faunal structures that increased the competitive pressure on the genus.

\section{Acknowledgements}

We would like to express our thanks to László Pongrácz (Györ), Katrin Krohmann (SMF), and Adam T. Halamski (ZPAL) and M. Borsuk-Białynicka (ZPAL) for providing us the fossil material in their care. We are grateful to two anonymous reviewers for their valuable comments and critical remarks. The study was supported by institutional support RVO67985831 of the Institute of Geology of the Czech Academy of Sciences. CA was supported by: Visiting Professor grant of the President's International Fellowship Initiative of the Chinese Academy of Science; Spanish Agencia Estatal de Investigación and the European Regional Development Fund of the European Union (CGL2016-76431-P); CERCA Program, Generalitat de Catalunya; Grant to Department of Science, Roma Tre University (MIUR-Italy Dipartimenti di Eccellenza, ART. 1, C. 314-337 L. 232/2016). BMS was supported by Xunta de Galicia (ED481B 2018/046, Axudas á etapa postdoutoral da Xunta de Galicia 2018-Modalidade A).

\section{REFERENCES}

Agadjanian A. K. \& ERbajeva M. A. 1983. - [Late Cenozoic rodents and lagomorphs of the USSR]. Nauka, Moscow, 189 p. (in Russian). Álvarez-SiERra M. A., DAAMS R., LACOMBA J. I., LÓPEZ-MARTínez N., Van der Meulen A. J., Sesé C. \& de Visser J. 1990. — Palaeontology and biostratigraphy (micromammals) of the continental Oligocene-Miocene deposits of the North-Central Ebro basin (Huesca, Spain). Scripta Geologica 94: 1-77.

Angelone C. 2007. - Messinian Prolagus (Ochotonidae, Lagomorpha, Mammalia) of Italy. Geobios 40: 407-421. https://doi. org/10.1016/j.geobios.2006.04.004

Angelone C. 2008a. — Prolagus italicus n. sp. (Ochotonidae, Lagomorpha, Mammalia) a new Pliocene species of peninsular Italy. Geobios 41: 445-453. https://doi.org/10.1016/j.geobios.2007.12.001

ANGELONE C. 2008b. - Family Ochotonidae (Lagomorpha) and its application in biochronology: some case studies from the PlioQuaternary of Eurasia. Quaternary International 179: 5-8. https:// doi.org/10.1016/j.quaint.2007.08.019

Angelone C. \& ČERMÁK S. 2015. - Two new species of Prolagus (Lagomorpha, Mammalia) from the Late Miocene of Hungary: taxonomy, biochronology, and palaeobiogeography. Paläontologische Zeitschrift 89: 1023-1038. https://doi.org/10.1007/ s12542-014-0247-z

Angelone C. \& Rook L. 2012. — Late Neogene and Quaternary lagomorphs from Tuscany: a revision based on specimens in Basel Naturhistorisches Museum and Florence University collections. Swiss Journal of Geosciences 131: 127-145. https://doi.org/10.1007/ s13358-011-0035-2

AngelOne C. \& SeSÉ C. 2009. - New characters for species discrimination within the genus Prolagus (Ochotonidae, Lagomorpha, Mammalia). Journal of Paleontology 83: 80-88. https://doi. org/10.1666/07-067R2.1 https://doi.org/10.1666/07-067R2.1

Angelone C. \& Veitschegger K. 2015. - MN10 Prolagus (Ochotonidae, Lagomorpha) from Austria: a new tile for the central European palaeogeography of the genus. Neues Jahrbuch für Geologie und Paläontologie 275: 1-10. https://doi.org/10.1127/ njgpa/2015/0444

ANGELONE C., ČERMÁK S. \& KOTSAKIS T. 2015. — The most ancient lagomorphs of Sardinia: an overview. Geobios 48: 287-296. https:// doi.org/10.1016/j.geobios.2015.06.002

Angelone C., Moncunill-Solé B. \& Kotsakis T. 2019. — Contribution of fossil Lagomorpha (Mammalia) to the refinement of the late Miocene-Quaternary palaeobiogeographical setting 
of Italy. Comptes Rendus Palevol 18: 1025-1040. https://doi. org/10.1016/j.crpv.2019.10.002

Angelone C., MonCunill-Solé B. \& Kotsakis T. 2020. — Fossil Lagomorpha (Mammalia) of Italy: systematics and biochronology. Rivista Italiana di Paleontologia e Stratigrafia 126: 157-187. https://doi.org/10.13130/2039-4942/13014

Averianov A. O. \& Tesakov A. S. 1998. — Lagomorphs (Mammalia, Lagomorpha) from early Pliocene locality of Kosyakino of the Northern Caucasus. Paleontological Journal 32: 305-309.

Bernor R. L., Koufos G. G., Woodburne M. \& ForteLIUS M. 1996. - The evolutionary history and biochronology of european and southeastern asian late Miocene and Pliocene hipparionine horses, in BERNOR R. L., FAHLBUSCH V. \& MiTTMANN H. W. (eds), The evolution of Western Eurasian Neogene mammal faunas. Columbia University Press, New York: 307-338.

BERZI A. 1967. - Lagomorphs from the type Villafranchian of Villafranca d'Asti (Italy). Preliminary note. Giornale di Geologia 35: 137-150.

BöHme M. 2003. - The Miocene Climatic Optimum: evidence from ectothermic vertebrates of Central Europe. Palaeogeography, Palaeoclimatology, Palaeoecology 195: 389-401. https://doi. org/10.1016/S0031-0182(03)00367-5

BöHme M., Ilg A. \& Winklhofer M. 2008. — Late Miocene "washhouse" climate in Europe. Earth and Planetary Science Letters 275: 393-401. https://doi.org/10.1016/j.epsl.2008.09.011

BRANDT J. F. 1855. — Beiträge zur näheren Kenntniss der Säugethiere Russlands. Mémoires de l'Académie impériale des sciences de St.-Pétersbourg 9: 1-365.

Casanovas-Vilar I., van den Hoek Ostende L. W., Furió M. \& MAdERN A. P. 2014. - The range and extent of the Vallesian Crisis (Late Miocene): new prospects based on the micromammal record from the Vallès-Penedès basin (Catalonia, Spain). Journal of Iberian Geology 40: 29-48. https://doi.org/10.5209/ rev_JIGE.2014.v40.n1.44086

ČERMÁK S. 2007. - New finds of Ochotonoma csarnotana (Lagomorpha, Ochotonidae) from the Pliocene of Hungary: a new look on the species. Neues Jahrbuch für Geologie und Paläontologie 246: 247-256. https://doi.org/10.1127/0077-7749/2007/0246-0247

ČERMÁK S. 2009. - The Plio-Pleistocene record of Hypolagus (Lagomorpha, Leporidae) from the Czech and Slovak Republics with comments on systematics and classification of the genus. Bulletin of Geosciences 84: 497-524. https://doi.org/10.3140/ bull.geosci. 1104

ČERMÁK S. \& ANGELONE C. 2013. - Revision of the type material of the Pliocene species Prolagus bilobus Heller, 1936 (Mammalia, Lagomorpha), with comments on the taxonomic validity of P. osmolskae Fostowicz-Frelik, 2010. Bulletin of Geosciences 88: 45-50. https://doi.org/10.3140/bull.geosci.1369

ČERMÁK S. \& WAGNER J. 2013. — The Pliocene record of Trischizolagus and Pliopentalagus (Leporidae, Lagomorpha, Mammalia) in Central Europe, with comments on taxonomy and evolutionary history of Leporinae. Neues Jahrbuch für Geologie und Paläontologie 268: 97-111. https://doi.org/10.1127/0077-7749/2013/0321

Czászár G. \& Kordos L. 2004. - Beremend, Köfejtő. Program, elöadáskivonatok, kirándulásvezetö, 7. Magyar Öslénytani Vándorgyülés 2004: 51-57.

DAHLMANN T. 2001. — Die Kleinsäuger der unter-pliozänen Fundstelle Wölfersheim in der Wetterau (Mammalia: Lipotyphla, Chiroptera, Rodentia). Courier Forschungsinstitut Senckenberg 227: 1-129.

DAHLMANN T. \& STORCH G. 1996. — Eine pliozäne (oberruschinische) Kleinsäugerfauna aus Gundersheim, Rheinhessen. 2. Insektenfresser: Mammalia, Lipotyphla. Senckenbergiana lethaea 76: 181-191. https://doi.org/10.1007/BF03042849

DAXNER G. \& FejFAR O. 1967. — Über die gattung Alilepus Dice, 1931 und Pliopentalagus Gureev, 1964 (Lagomorpha, Mammalia). Annalen des Naturhistorischen Museums in Wien 71: 37-55.

De Schepper S., Groeneveld J., NaAfs B. D. A., van Rent- erghem C., Hennissen J., Head M. J., Louwye S. \& FABIAN K. 2009. - Northern Hemisphere Glaciation during the Globally Warm Early Late Pliocene. PLoS ONE 8(12): e81508. https://doi.org/10.1371/journal.pone.0081508

De Schepper S., Gibbard P. L., Salzmann U. \& Ehlers J. 2014. - A global synthesis of the marine and terrestrial evidence for glaciation during the Pliocene Epoch. Earth-Science Reviews 135: 83-102. https://doi.org/10.1016/j.earscirev.2014.04.003

DiCE L. R. 1917. - Systematic position of several tertiary lagomorphs. University of California Publications, Bulletin of the Department of Geology 10: 179-183.

Erbajeva M. A. 1988. - [Cenozoic Pikas (Taxonomy, Systematics, Phylogeny)]. Nauka, Moscow, 224 p. (in Russian).

Erbajeva M. A. \& Shushpanov K. I. 1988. - [Pliocene pikas of Moldavia]. Vestnik Zoologii 4: 55-60. (in Russian).

FEJFAR O. 1961. - Die plio-pleistozänen Wirbeltierfaunen von Hajnáčka und Ivanovce (Slowakei), ČSSR. III. Lagomorpha. Neues Jahrbuch für Geologie und Paläontologie, Monatshefte 5: 267-282.

FEJFAR O. \& HEINRICH W.-D. 1983. - Arvicoliden-Sukzession und Biostratigraphie des Oberpliozäns und Quartärs in Europa. Schriftenreihe für geologische Wissenschaften 19/20: 61-109.

FejFar O. \& STORCH G. 1990. — Eine pliozäne (ober-ruscinische) Kleinsäugerfauna aus Gundersheim, Rheinhessen: 1. Nagetiere: Mammalia, Rodentia. Senckenbergiana lethaea 71: 139-184.

Fejfar O., HeInRICH W.-D. \& LindaY E. H. 1998. — Updating the Neogene Rodent biochronology in Europe. Mededelingen Nederlands Instituut voor Toegepaste Geowetenschappen TNO 60: 533-554.

Fejfar O., Storch G. \& Tobien, H. 2006. - Gundersheim 4, a third Ruscinian micromammalian assemblage from Germany. Palaeontographica A 278: 97-111. https://doi.org/10.1127/ pala/278/2006/97

Fladerer F. A. \& ReINer G. 1996. - Evolutionary shifts in the first premolar pattern of Hypolagus beremendensis (Petényi, 1864) (Lagomorpha, Mammalia) in the Plio-Pleistocene of Central Europe. Acta Zoologica Cracoviensia 39: 147-160.

FostowiCZ-FreliK Ł. 2010. - A new species of Pliocene Prolagus (Lagomorpha: Ochotonidae) from Poland in the northermost record of the genus. Journal of Vertebrate Paleontology 30: 609612. https://doi.org/10.1080/02724631003621789

GANOPOLSKI A. \& CALOV R. 2011. - The role of orbital forcing, carbon dioxide and regolith in $100 \mathrm{kyr}$ glacial cycles. Climate of the Past 7: 1415-1425. https://doi.org/10.5194/cp-7-1415-2011

GuREEV A. A. 1960. - [Lagomorphs (Lagomorpha) from the Oligocene of Mongolia and Kazakhstan]. Trudy Paleontologicheskogo Instituta Akademii Nauk SSSR 77: 5-34. (in Russian).

GurEeV A. A. 1964. - [Fauna of the USSR (Lagomorpha), Vol. 3 (10)]. Nauka, Moscow \& Leningrad. 276 p. (in Russian).

HeLler F. 1936. — Eine oberpliozäne Wirbeltierfauna aus Rheinhessen. Neues Jahrbuch für Mineralogie, Geologie und Paläontologie, Abteilung B 76: 99-160.

HordiJK K. \& VAN DER Meulen A. J. 2010. - Systematics of resident species of Lagopsis and Prolagus (Ochotonidae, Lagomorpha, Mammalia) from the late early and middle Miocene of northeastern Central Spain. Geologica Ultraiectina 333: 17-85.

JÁNOSSY D. 1972. — Middle Pliocene microvertebrate fauna from the Osztramos Loc. 1. (Northern Hungary). Annales historiconaturales Musei nationalis hungarici 64: 27-50.

JÁNOSSY D. 1986. - Pleistocene vertebrate faunas of Hungary. Akadémiai Kiadó, Budapest, 208 p.

KoENIGSWALD W. vON \& TOBIEN H. 1990. - Important arvicolid faunas from the Late Pliocene to Early Holocene in Westen Germany (FRG), in FejFar O. \& HeInRICH W.-D. (eds), International symposium evolution, phylogeny and biostratigraphy of arvicolids (Rodentia, Mammalia). Czech Geological Survey, Prague: 231-254.

KÖNIG C. D. E. 1825. - Icones Fossilium Sectiles, Centuria Prima. G.B. Sowerby, London, 4 p. 
Kordos L. 1991. - Upper Pliocene paleovertebrate localities, Beremend, Villány Mts. Magyarország geológiai alapszevényei 1991: $1-6$

Kormos T. 1930. - Beiträge zur Präglazialfauna des Somlyóberges bei Püspökfürdo. Állattani Közlemények 27: 40-62.

Kovar-EDER J., JeCHOREK H., KVAČEK Z. \& PARASCHIV V. 2008. The Integrated Plant Record: An Essential Tool For Reconstructing Neogene Zonal Vegetation In Europe. Palaios 23: 97-111. https://doi.org/10.2110/palo.2006.p06-039r

KOWALSKI K. 1960. — Cricetidae and Microtidae from the Pliocene of Weze (Poland). Acta Zoologica Cracoviensia 5: 447-506.

KOWALSKI K. 1990. - Stratigraphy of Neogene mammals in Poland, in Linday E. H., Fahlbusch V. \& Mein P. (eds), European Neogene Mammal Chronology. Plenum Press, New York: 193-209.

KRETZOI M. 1954. - Bericht über die calabrische (villafranchische) Fauna von Kislang, Kom. Fejér. Állami Földtani Intézet Evijjelentése az 1953 1: 239-265.

KRETZOI M. 1956. — Die altpleistozänen Wirbeltierfaunen des Villányer Gebirges. Geologica hungarica, Series palaeontologica 27: 1-264.

KRETZOI M. 1959. - Insectivoren, Nagetiere und Lagomorphen der jüngstpliozänen Fauna von Csarnóta im Villáyer Gebirge (Südungarn). Vertebrata Hungarica 2: 237-246.

Kretzor M. 1962. - Fauna und Faunenhorizont von Csarnóta. Jahresbericht der Ungarischen Geologischen Anstalt 1959: 297-395.

LiNK D. H. F. 1795. - Beiträge zur Naturgeschichte. Rostock und Leipzig 2: 1-126.

LINNAEUS C. 1758. - Systema naturae per Regna tria naturae, secundum Classes, Ordines, Genera, Species. Tomus I. Editio decima, reformata. Laurentii Salvii, Holmix, 824 p.

López Martínez N. 1974. - Evolution de la lignée PiezodusProlagus (Lagmorpha, Ochotonidae) dans le Cenozoïque d'Europe Sud-Occidentale. Unpublished PhD Thesis. Université des Science et techniques du Languedoc, Académie de Montpellier, 165 p.

LÓPEZ MARTínez N. 1989. - Revisión sistemática y bioestratigráfica de los Lagomorpha (Mammalia) del Terciario y Cuaternario inferior de España. Memorias del Museo Paleontológico de la Universidad de Zaragoza 3: 1-350.

LÓPEZ MARTÍNEZ N. 2001. - Paleobiogeographical history of Prolagus, an European ochotonid (Lagomorpha). Lynx (n.s.) 32: 215-231.

López MARTínez N. \& Thaler L. 1975. — Biogéographie, évolution et compléments à la systématique du groupe d'Ochotonides Piezodus-Prolagus (Mammalia, Lagomorpha). Bulletin de la Société géologique de France 17: 850-866. https://doi.org/10.2113/gssgfbull.S7-XVII.5.850

López Martínez N., Sesé Benito C. \& Sanz García J. L. 1977. La microfauna (Rodentia, Insectivora y Reptilia) de las fisuras del Mioceno medio de Escobosa de Calatañazor (Soria, España). Acta Geologica Hispanica 12, 60-68. http://hdl.handle.net/10261/3393

Lunt D. J., Foster G. L., Haywood A. M. \& Stone E. J. 2008. Late Pliocene Greenland glaciation controlled by a decline in atmospheric CO2 levels. Nature 454: 1102-1105. https://doi. org/10.1038/nature07223

Maridet O., Escarguel G., Costeur L., Mein P., Hugueney M. \& LEGENDRE S. 2007. - Small mammal (rodents and lagomorphs) European biogeography from the Late Oligocene to the mid Pliocene. Global Ecology and Biogeography 16: 529-544. https:// doi.org/10.1111/j.1466-8238.2006.00306.x

MASINI F. 1989. - Prolagus sorbinii, a new ochotonid (Mammalia, Lagomorpha) from the Messinian of Italy. Bollettino della Societò Paleontologica Italiana 28: 295-306.

MAYHEW D. F. 2012. - Revision of the fossil vole assemblage (Mammalia, Rodentia, Arvicolidae) from Pleistocene Deposits at Kisláng, Hungary. Palaeontology 55: 11-29. https://doi. org/10.1111/j.1475-4983.2011.01115.x

Michaux J. 1971. - Arvicolinae (Rodentia) du Pliocéne terminal et du Quatemaire ancien de France et d'Espagne. Palaeovertebrata 4: 137-214. https://doi.org/10.18563/pv.4.5.137-214
NADACHOWSKI A. 1990. - Review of fossil Rodentia from Poland (Mamalia). Senckenbergiana Biologica 70: 229-250.

Nadachowski A., Marciszak A., Rzebik-Kowalska B. \& GorNig W. 2015. - Sesja terenowa C. Raciszyn. Fauna kopalnaRaciszyn 1 (RN1), in KicińsKa D., STEFANIAK K. \& SZYNKIEWICZ A. (eds), Przewodnik sesji terenowych. Materiaty 49. Sympozjum Speleologicznego, Zatęcze Wielkie 22-25.10.2015. Sekcja Speleologiczna Polskiego Towarzystwa Przyrodników im. Kopernika, Kraków: 50-51.

Nesin V. A. \& NADACHOwsKi A. 2001. — Late Miocene and Pliocene small mammal faunas (Insectivora, Lagomorpha, Rodentia) of southeastern Europe. Acta Zoologica Cracoviensia 44: 107-135.

PETÉNYI S. J. 1864. — A beremendi mészkőbánya természetrajz-és őslénytanilag Petényi Salamon által leírva, in KUBINYI F. (ed.), Petényi S. János Hátrahagyott munkái. Magyar Tudományos Akademia, Pest: 35-81.

POMEL M. 1853. - Catalogue méthodique et descriptif des vertébrés fossiles découverts dans le bassin hydrographique supérieur de la Loire, et surtout dans la vallée de son affluent principal, l'Allier. J.-B. Baillière, Paris, 193 p.

PONGRÁCZ L. 1999. - A beremendi Szölö-hegy természettudományi kutatásának 150 éve. Petényi-emlékkönyv, Beremend, 149 p.

Popov V. V. 2001. — Late Pliocene voles (Mammalia: Arvicolidae) from Varshets (North Bulgaria). Acta Zoologica Cracoviensia 44: 143-172.

Popov V. V. 2003. — Late Pliocene Soricidae (Insectivora, Mammalia) from Varshets (North Bulgaria). Acta Zoologica Cracoviensia 46: 43-72.

POPOV V. V. 2004. - Pliocene small mammals (Mammalia, Lipotyphla, Chiroptera, Lagomorpha, Rodentia) from Muselievo (North Bulgaria). Geodiversitas 26: 403-491.

Popov S. V., Rögel F., Royanov A. Y., Steininger F. F., ShCHERBA I. G. \& KovÁČ M. 2004. - Lithological-paleogeographic maps of Paratethys. 10 Maps Late Eocene to Pliocene. Courier Forschungsinstitut Senckenberg 250: 1-46.

Rabeder G. 1981. - Die Arvicoliden (Rodentia, Mammalia) aus dem Pliozän und dem ältesten Pleistozän von Niederösterreich. Beiträge zur Paläontologie von Österreich 10: 1-373.

RABEDER G. \& VERGINIS S. 1987. — Die plio-pleistozänen löessprofile von Stranzendorf und Krems (Niederösterreich). Griechische Geographische Gesellschaft 1. Panhellenische Geographen-Tagung Athen. 9: 285-306.

Radulesco C. \& SAmson P. 1967. - Contribution à la connaissance du complexe faunique de Măluşteni-Bereşti (Pléistocène inférieur), Roumanie I. Ord. Lagomorpha, Fam. Leporidae. Neues Jahrbuch für Geologie und Paläontologie, Monatshefte 9: 544-563.

RAUP D. M. \& CRICK R. E. 1979. - Measurement of faunal similarity in paleontology. Journal of Paleontology 53: 1213-1227.

RePENNING CH. A. 1967. - Subfamilies and Genera of the Soricidae. Classification, historical zoogeography and temporal correlation of the shrews. United States Survey Professional Paper 565: 1-74. https://doi.org/10.3133/pp565

Reumer J. W. F. 1984. - Ruscinian and early Pleistocene Soricidae (Insectivora, Mammalia) from Tegelen (The Nederlands) and Hungary. Scripta Geologica 73: 1-173.

Reumer J. W. F. 1989. - Speciation and evolution in the Soricidae (Mammalia: Insectivora) in relation with the paleoclimate. Revue Suisse Zoology 96: 81-90. https://doi.org/10.5962/bhl.part.117758

REumer J. W. F. \& Wessels W. 2003. - Distribution and migration of Tertiary mammals in Eurasia. A volume in honour of Hans de Bruijn. Deinsea 10, 576 p.

ROMAN F. \& VIRET J. 1930. — Le Miocène continental de l'Armagnac et le gisement burdigalien de La Romieu (Gers), in DE MARgerie E., Barrois Ch., Bertrand L., Bertrand P. \& BourCART J. (eds), Livre Jubilaire de la Société géologique de France 2. Société Géologique de France, Paris: 577-604.

RÖssner G. E. \& HeIssig K. 1999. - The Miocene Land Mammals of Europe. Verlag Dr. Friedrich Pfeil, Munich, 516 p. 
ŞEN Ş. 1998. — Pliocene vertebrate locality of Çalta, Ankara, Turkey. 4. Rodentia and Lagomorpha. Geodiversitas 20: 359-378.

Şen Ş., Bouvrain G. \& GeraAdS D. 1998. - Pliocene vertebrate locality of Çalta, Ankara, Turkey. 12. Paleoecology, biogeography and biochronology. Geodiversitas 20: 497-510.

SHI N. 1994. - The Late Cenozoic Stratigraphy, Chronology, Palynology and Environmental Development in the Yushe Basin, North China. Striae 36: 1-90.

SKOCZEN S. 1980. — Scaptomychini Van Valen, 1967, Urotrichini and Scalopini Dobson, 1883 (Insectivora, Mammalia) in the Pliocene and Pleistocene of Poland. Acta Zoologica Cracoviensia 24: 411-448.

STONE W. 1900. — Descriptions of a New Rabbit from the Liu Kiu Islands and a New Flying Squirrel from Borneo. Proceedings of the Academy of Natural Sciences of Philadelphia 52: 460-463.

Sue C., Delacou B., Champagnac J.-D., Allanic C., Tricart P. \& BURKHARD M. 2007. - Extensional neotectonics around the bend of the Western/Central Alps: An overview. International Journal of Earth Sciences 96: 1101-1129. https://doi.org/10.1007/ s00531-007-0181-3

SUlimSKI A. 1959. — Pliocene Insectivores from Węże (Owadożerne z plioceńskiej brekcji kostnej z Wężów). Acta Palaeontologica Polonica 4: 119-179.

SULIMSKI A. 1962. - O nowym znalezisku kopalnej fauny kregowców w okolicy Działoszyna. Przegląd Geologiczny 10: 219-223.

SULIMSKI A. 1964. - Pliocene Lagomorpha and Rodentia from Węże 1 (Poland). Acta Palaeontologica Polonica 9: 149-262.

SULIMSKI A. \& SZYNKIEWICZ A. 1994. - Pliocene small mammals from Raciszyn 1 (Cracow-Wieluń Upland, Central Poland), in Neogene and Quaternary Mammals of the Palearctic: Abstracts of the Conference in Honour of Prof. Kazimierz Kowalski. Polish Academy of Sciences, Kraków: 69.

SyCH L. 1965. - Fossil Leporidae from the Pliocene and the Pleistocene of Poland. Acta Zoologica Cracoviensia 10: 1-88.

SZYNKIEWICZA. \& JAGIEŁŁO M. 2015. - Zjawiska krasowe w rejonie Raciszyna, in Kicińska D., STEFAniaK K., SzYNKIEWICZ A. (eds), Przewodnik sesji terenowych. Materiahy 49. Sympozjum Speleologicznego, Zatęcze Wielkie 22-25.10.2015. Sekcja Speleologiczna Polskiego Towarzystwa Przyrodników im. M. Kopernika, Kraków: 43-50.

Tan N., Ramstein G., Dumas C., Contoux C., Ladant J.-B., SepULCHRE P., ZHANG Z. S. \& De SCHEPPER S. 2017. - Exploring the MIS M2 glaciation occurring during a warm and high atmospheric CO2 Pliocene background climate. Earth and Planetary Science Letters 472: 266-276. https://doi.org/10.1016/j.epsl.2017.04.050

Tedford R. H., Flynn J. L., Qiu Z., Opdyke H. \& Doens W. R. 1991. - Yushe basin, China, Paleomagnetically calibrated mammalian biostratigraphic standard for the Late Neogene of eastern Asia. Journal of Vertebrate Paleontology 11:519-526. https://doi.org/10.1080/02724634.1991.10011420

TERZEA E. 1997. - Biochronologie du pliocène du bord Méridional du bassin Dacique (Roumanie). Mémoires et Travaux de l'Institut de Montpellier 21: 649-660.

Tesakov A. S. \& Averianov A. O. 2002. - Prolagus (Lagomorpha, Prolagidae) from the Pliocene of Moldova and Ukraine. Paleontological Journal 36: 80-86.
ToBIEN H. 1935. — Über die pleistozänen und postpleistozänen Prolagusformen Korsikas und Sardiniens. Berichte der naturforschenden Gesellschaft zu Freiburg im Breisgau 34: 253-344.

Tobien H. 1977. - 7. Fauna, in BoenigK W., Brelie G., BrunnaCKer K., Kempf E. K., Kočí A., Schirmer W., Stadler G., STREIT R. \& Tobien H. (eds), Jungtertiär und Quartär im HorloffGraben, Vogelsberg. Geologische Abhandlungen Hessen 75: 65-68.

Tobien H. 1980. — Säugerfaunen von der Grenze Pliozän/Pleistozän in Rheinhessen. 1. Die Spaltfüllungen von Gundersheim bei Worms. Mainzer geowissenschaftliche Mitteilungen 8: 209-218.

Topachevsky V. O. 1962. - [On the Geological Age of Early Alluvial deposits of the Lower Dnieper Valley]. Geologicheskii zhurnal 22: 106-109 (in Ukrainian).

ÜNAY E. \& DE BRUIJN H. 1998. - Plio-Pleistocene rodents and lagomorphs from Anatolia. Mededelingen Nederlands Instituut voor Toegepaste Geowetenschappen TNO 60: 431-466.

Van der Meulen A. \& VAn Kolfschoten T. 1986. — Review of the Late Turolian to Early Biharian mammal faunas from Greece and Turkey. Memoria Società Geologia Italiana 31: 201-211.

VAN DE WEERD A. 1979. - Early Ruscinian rodents and lagomorphs (Mammalia) from the lignites near Ptolemais (Macedonia Greece). Proceedings of the Koninklijke Nederlandse Akademie van Wetenschappen, Series B Physical Sciences 82: 127-168.

VAN DE WeERD A. \& DAAMS R. 1978. — Quantitative composition of rodent faunas in the Spanish Neogene and palaeoecological implications. Proceedings of the Koninklijke Nederlandse Akademie van Wetenschappen, Series B Physical Sciences 81: 448-473.

Van de Weerd A., Reumer J. W. F. \& De Vos J. 1982. — Pliocene mammals from Apolakkia Formation (Rhodes, Greece). Proceedings of the Koninklijke Nederlandse Akademie van Wetenschappen, Series B Physical Sciences 85: 89-112.

VIRET J. 1929. - Les faunes de mammifères de l'Oligocène supérieur de la Limagne bourbonnaise. Annales de l'Université de Lyon, nouvelle série 1 47: 1-327.

WAGNER R. 1829. - Über die Knochenbrekzie in Sardinien und die darin gefundenen Thiere, so wie über einige andere hieher gehörige Erscheinungen. Archiv für die gesammte Naturlehre 15: 10-31.

WaGNER J., ČERMÁK S., HoráČEK I., FejFAR O. \& MiHeVC A. 2009. New mammalian fossil records refining a view on Early/Late Pliocene faunal turnover in Central Europe. Journal of Vertebrate Paleontology 29 (Supl. 3): 197A.

Wible J. R. 2007. - On the Cranial Osteology of the Lagomorpha. Bulletin of Carnegie Museum of Natural History 39: 213234. https://doi.org/10.2992/0145-9058(2007)39[213:OTC OOT]2.0.CO;2

Xue X., Zhang Y. \& Yue L. 2006. - Paleoenvironments indicated by the fossil mammalian assemblages from red clay-loess sequence in the Chinese Loess Plateau since 8.0 Ma B.P. Science in China Series D 49: 518-530. https://doi.org/10.1007/ s11430-006-0518-y

Zachos J. C., Pagani M., Sloan L. C., Thomas E. \& BilLUPS K. 2001. - Trends, rhythms, and aberrations in global climate $65 \mathrm{Ma}$ to present. Science 292: 686-693. https://doi. org/10.1126/science.1059412 